Article

\title{
Can Land Management Buffer Impacts of Climate Changes and Altered Fire Regimes on Ecosystems of the Southwestern United States?
}

\author{
Rachel Loehman ${ }^{1, *}$, Will Flatley ${ }^{2}$, Lisa Holsinger ${ }^{3}$ and Andrea Thode ${ }^{4}$ \\ US Geological Survey, Alaska Science Center, Anchorage, AK 99508, USA \\ 2 Department of Geography, University of Central Arkansas, Conway, AR 72035, USA; wflatley@uca.edu \\ 3 US Forest Service Rocky Mountain Research Station, Missoula, MT 59808, USA; lisamholsinger@fs.fed.us \\ 4 School of Forestry, Northern Arizona University, Flagstaff, AZ 86011, USA; andi.thode@nau.edu \\ * Correspondence: rloehman@usgs.gov; Tel.: +1-907-786-7089
}

Received: 15 February 2018; Accepted: 4 April 2018; Published: 7 April 2018

\begin{abstract}
Climate changes and associated shifts in ecosystems and fire regimes present enormous challenges for the management of landscapes in the Southwestern US. A central question is whether management strategies can maintain or promote desired ecological conditions under projected future climates. We modeled wildfire and forest responses to climate changes and management activities using two ecosystem process models: FireBGCv2, simulated for the Jemez Mountains, New Mexico, and LANDIS-II, simulated for the Kaibab Plateau, Arizona. We modeled contemporary and two future climates-"Warm-Dry" (CCSM4 RCP 4.5) and "Hot-Arid" (HadGEM2ES RCP 8.5)—and four levels of management including fire suppression alone, a current treatment strategy, and two intensified treatment strategies. We found that Hot-Arid future climate resulted in a fundamental, persistent reorganization of ecosystems in both study areas, including biomass reduction, compositional shifts, and altered forest structure. Climate changes increased the potential for high-severity fire in the Jemez study area, but did not impact fire regime characteristics in the Kaibab. Intensified management treatments somewhat reduced wildfire frequency and severity; however, management strategies did not prevent the reorganization of forest ecosystems in either landscape. Our results suggest that novel approaches may be required to manage future forests for desired conditions.
\end{abstract}

Keywords: wildfire; climate change; management; resilience; modeling; southwest

\section{Introduction}

Gradual changes in landscape composition and structure are predicted with shifting climate patterns [1-5]. However, climate changes occur in the context of increased landscape disturbance that can catalyze abrupt changes in ecosystems [6-8]. In particular, global ecosystems are highly influenced by fire disturbance [9-12]. In fire-adapted, fire-prone systems, landscape patterns and vegetation distributions are determined primarily by reciprocal interactions with fire $[13,14]$ and then by fine-scale interactions within and among species (e.g., competition and dispersal) and their surrounding environment (e.g., climate and edaphic conditions) [15].

In the southwestern US, fire regimes have been altered by land management and climate changes. A hundred-plus years of livestock grazing, logging, and fire exclusion have altered pre-European era fire frequencies, creating increased surface fuel loads, dense, fuel-rich forests, and reduced structural and spatial heterogeneity of vegetation, especially in dry conifer forests with frequent-fire regimes (typically, those with fire return intervals $<35$ years) [16-18]. Fires in these forests are likely to be more intense with larger patches of high-severity fire than occurred historically [19-23], reducing biodiversity, 
ecological function, and resilience [12,17]. Observed 20th and 21st century anthropogenic climate changes of warming temperatures and an earlier onset of snowmelt have increased the length of fire seasons and lowered fuel moistures, making large portions of the landscape flammable for longer periods of time [21,24], and widespread, regional fire years have been associated with prolonged droughts [13,25,26].

Understanding how to manage changing fire regimes and fuel conditions will be a central challenge for decades to come, as warmer and drier climates cause more frequent, more severe, and larger fires than occurred historically $[9,10,27,28]$. Wildfires that are large and severe, that overlap in space or time, or that are at or beyond the bounds of historical range of variability can abruptly reorganize ecosystems $[11,29,30]$. In the Southwest, this reorganization may represent a tipping point in which changing climate and disturbance processes create novel fuelscapes, thus setting the stage for future fire regimes that are significantly different from those that have existed in the past. These regime changes pose serious threats to ecosystem integrity and resilience [31].

Several recent papers have addressed the appropriateness and effectiveness of fire management and forest restoration activities under changing climates [32-35]. A common finding is the limited ability of current strategies to ameliorate undesired wildfire impacts in many ecological systems, particularly given the potentiating effects of warmer, drier climates on fire frequency and severity. Littell et al. 2009 [32], in an analysis of the relationship of climate and wildfire area burned in the western US, concluded that fuel treatments may mitigate wildfire vulnerability in fuel-limited systems, but that treatments may be less effective in systems where future fire patterns are influenced more by climate than by fuels. Stephens et al. 2013 [36] suggested that new strategies to mitigate and adapt to increased fire are needed to sustain forest landscapes (e.g., promote resilience), including the restoration of historical stand conditions in high frequency, low-to-moderate severity fire regimes, while allowing for shifts away from historical forest structure and composition in forests with low-frequency, high-severity fire regimes. Facilitating the adaptation of forests to changing climate and fire regimes may ultimately create more resilient systems as vegetation communities come into equilibrium with climate [35]. For example, Schoennagel et al. 2017 [33] indicated the importance of adaptive management approaches that include increased use of prescribed fire, much reduced fire suppression, and recognition of the limited ability of fuel treatments to alter regional fire patterns.

The need for a better understanding of the potential impacts of climate changes on ecosystems is reaching new levels of urgency. To guide management strategies, current, scientifically credible information on how landscapes will respond to the synergistic interactions of climate and disturbance processes is required [37]. Research is ongoing, but projections of future conditions are somewhat uncertain and rarely produce the level of accuracy and precision needed by resource managers [38]. A core question central to fire and ecosystem management in fire-prone ecosystems is whether fuels and fire management strategies can be designed to maintain or promote desired ecological conditions under projected future climate and fire regimes [33]. As part of a Joint Fire Science Program project funded to improve understanding of future ecosystem and fire regime dynamics and management impacts, we modeled a range of climate and land management scenarios using two spatially explicit, mechanistic ecosystem-fire models, FireBGCv2 and LANDIS-II. Our simulation landscapes are the Jemez Mountains in northern New Mexico, modeled with FireBGCv2 (hereafter FireBGCv2-Jemez), and the Kaibab Plateau in Arizona, modeled with LANDIS-II (hereafter LANDIS-II-Kaibab) (Figure 1). Models were previously parameterized for respective study areas, providing an opportunity to compare outcomes and evaluate the interactions of climate, fire, and management under a common set of climate and management scenarios. Modeled management strategies were collaboratively developed by southwestern US researchers and managers as plausible responses to changing forests and fire regimes. We used our models to address three related topics for ponderosa pine and dry mixed conifer forests in each simulation landscape: (1) Will future climate cause fundamental changes in forests and fire regimes? (2) Will current management approaches be effective in preventing fundamental changes in forests and fires under future climates? (3) Could shifting climate regimes require new management approaches, or can fundamental ecological characteristics of southwestern forests be preserved through an intensification of current strategies? 


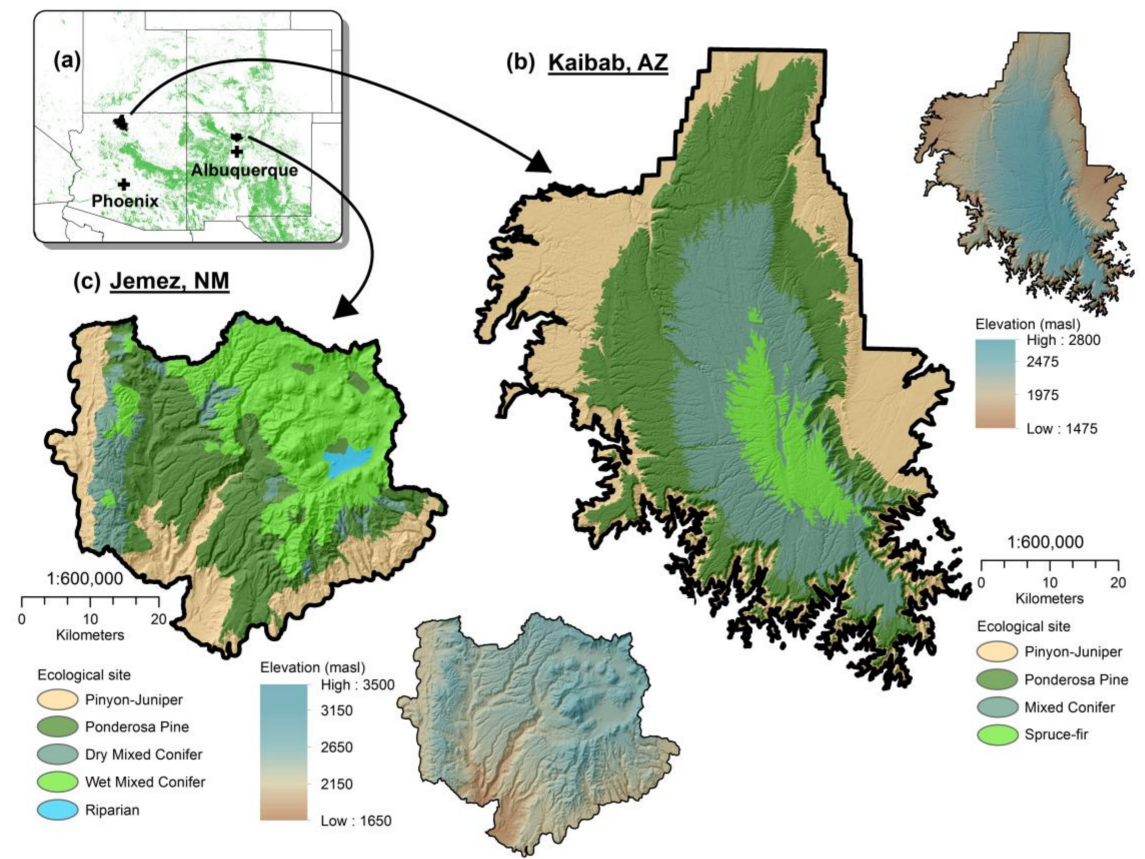

Figure 1. (a) Jemez, NM (FireBGCv2-Jemez) and Kaibab, AZ (LANDIS-II-Kaibab) study areas. Green shading denotes distribution of forests that historically experienced high frequency $(\leq 35$ Year Fire Return Interval) low- to mixed-severity fires (Fire Regime Group 1, LANDFIRE Program, Rollins 2009 [39]; (b) FireBGCv2-Jemez ecological setting and surface elevation; (c) LANDIS-II-Kaibab ecological setting and surface elevation.

\section{Materials and Methods}

\subsection{Study Areas}

The $\sim 180,000$ ha FireBGCv2-Jemez study area (Figure 1a,c) is a mainly forested, fire-adapted landscape of mesas and canyons (elevation range 1500-3500 meters above sea level (masl)). Landscape vegetation is strongly influenced by elevation and aspect, which are highly correlated with plant-available moisture [40]. Upper elevation ( 2900 to 3500 masl), mesic forests contain Engelmann spruce (Picea engelmanii), corkbark fir (Abies lasiocarpa var. arizonica), and blue spruce (P. pungens); upper-middle elevation ( 2300 to 2900 masl), dry mixed conifer forests consist of ponderosa pine (Pinus ponderosa var. scopulorum), Douglas-fir (Pseudotsuga menziesii var. glauca), white fir (Abies concolor), limber pine (Pinus flexilis), and southwestern white pine (Pinus strobiformis), with intermixed stands of aspen (Populus tremuloides); lower-middle elevations ( 2100 to 2600 masl) are comprised of pure or nearly pure stands of ponderosa pine with Gambel oak (Quercus gambelii) understory; and dry woodlands of piñon pine (Pinus edulis) and juniper (primarily Juniperus monosperma) occur at lower elevations of 1500 to 2100 masl [40-42]. Regional climate is semi-arid with a bimodal precipitation pattern with peaks in winter (December-January) and summer (July-August; summer monsoon) [41]. Prior to persistent and substantial European settlement in the mid-1800s, much of the Jemez landscape was dominated by frequent, low-intensity surface fires with low overstory tree mortality, high understory tree mortality, and the regular consumption of surface fuels [41,43-45]. Large wildfires that have burned across the Jemez Mountains in the past five decades have included larger components of high-severity fire than occurred in the past, causing high levels of tree mortality, delayed forest regeneration, and erosion and other geomorphological changes $[46,47]$.

The Kaibab Plateau (Figure 1a,b) is a broad, high elevation limestone plateau located in northern Arizona, encompassing 335,000 ha in Grand Canyon National Park (GCNP) and the North Kaibab Ranger District (NKRD) of the Kaibab National Forest. Elevation within the study landscape ranges from 
1439 to 2830 masl, supporting a range of forest types that are distributed along a gradient of increasing moisture availability and decreasing temperature with increasing elevation. Forest types are similar to the Jemez landscape with low elevation piñon-juniper (primarily J. osteosperma), and Gambel oak, and mid elevation ponderosa pine. At mid to high elevations, dry mixed conifer and wet mixed conifer forests intermix and are composed of ponderosa pine, Douglas fir, white fir, blue spruce, Engelmann spruce, subalpine fir (Abies lasiocarpa), and aspen. Forests at the highest elevations are composed of Engelmann spruce, subalpine fir, and aspen [48,49]. Climate is similar to the Jemez landscape, with winter precipitation peaking slightly later (January-February) and lightning ignitions occurring most frequently in July $[50,51]$. Historically, frequent surface fires burned at intervals of about six to nine years in ponderosa pine and about seven to 31 years in dry mixed conifer forests [52,53]. Higher elevation forests experience less frequent, mixed- to high-severity fires [54,55]. The Kaibab Plateau has experienced large, high-severity fires in recent years [56].

\subsection{Ecological Modeling}

\subsubsection{Firebgcv2-Jemez}

FireBGCv2 (Fire BioGeoChemical model Version 2) is a spatially explicit, mechanistic ecosystem process model developed to evaluate interactions of climate, disturbance, and vegetation over long time scales [57-60]. Model details are described in Keane et al. 2011 [61] and in Supplement 1. Required model inputs are ecological site and stand maps, daily weather for ecological sites, fire regime and vegetation parameters, and initializing stand (plot) vegetation and fuels data. Ecological sites (ponderosa pine, 61,451 ha; wet mixed conifer, 60,795 ha; piñon-juniper, 41,009 ha; dry mixed conifer, 16,039 ha; and riparian, 1824 ha; Figure 1c) were mapped from the LANDFIRE environmental site potential (ESP) data layer [39], resampled to $90 \mathrm{~m}$, and generalized based on nearest neighbors to reduce fine-scale heterogeneity. Initial stand boundaries were defined using the LANDFIRE biophysical settings layer, and plot data from 84 plots collected across the Jemez landscape in 2012-2013 (for detailed field methods see $[57,59]$ ) or obtained from the Forest Inventory and Analysis Program (http:/ / www.fia.fs.fed.us/) were assigned to stands based on similarities of dominant species, elevation, slope, and aspect. Weather data were obtained from the Jemez Springs National Climatic Data Center cooperative weather station (CO-OP ID 294369-2) (NCDC 2011) and were extrapolated across sites [62,63]. Historical fire frequency and size distributions were derived from fire history studies for southwestern ecosystems [18,64-72], including local studies $[41,44,73]$. Vegetation species parameters were gleaned from literature, previous FireBGCv2 projects [57-59,66,74], and field data. We adjusted fire size and frequency parameters until the model simulated landscape fire return intervals that were consistent with available fire history records [18,64-68,70-72,75]. We adjusted biological tree species parameters (e.g., shade tolerance, growing degree days, cone crop probability, bark thickness) until modeled spatial distributions and individual species basal area characteristics matched published estimates for southwest vegetation communities under non-managed conditions (e.g., without suppression, logging, or other activities) [69,76-78].

\subsubsection{LANDIS-II-Kaibab}

LANDIS-II is a spatially interactive, process-based landscape simulation model well suited for large spatial and temporal scales [79]. Specifics of the model structure, inputs, and validation for the Kaibab Plateau study landscape are described in Flatley and Fulé 2016 [80] and in Supplement 1. We used the Biomass Succession extension for LANDIS-II to model forest growth, competition, succession, and individual species response to climate change [81]. Inputs for the Biomass Succession extension, including species growth parameters across the varying environmental site conditions, climate scenarios, and time steps, were estimated using the Climate-Forest Vegetation Simulator [82]. The Dynamic Fire and Fuels (DFF) extension (v2.0) [83] simulated wildfire occurrence and spread according to site specific inputs of daily fire weather, ignition rates, and fire duration distributions. Daily fire weather data (ca. 1995-2013) was obtained from seven Remote Automated Weather Stations located within or adjacent to the study 
landscape (http:/ / www.raws.dri.edu). The DFF extension simulated individual fires according to daily fire weather (for more detail see Supplement 1), then burned areas were aggregated within each 5-yr time step. Management actions were implemented with the Biomass Harvest extension (v2.1) [84], which reduces the biomass of cohorts according to species and age ranges specified in management prescriptions and alters fuel characteristics. We created initial forest conditions by preceding each model run with a 600-year spinup under contemporary climate conditions and historical fire frequencies, followed by 120 years of fire suppression and then biomass removal to simulate 20th century logging on forest service lands. We used a 1-ha cell resolution and each extension operated at a five-year time step.

\subsection{Modeling Scenarios}

We modeled 20 replicates of 100-year simulations for 12 factorial scenarios of climate (contemporary and two climate change factors, Figure 2) and management (wildfire suppression only, current management, and two intensified strategies). Contemporary climate in FireBGCv2 was a repeating loop of daily instrumental weather (1987-2006) from the Jemez NCDC station, extrapolated across sites [62,63]. For LANDIS-II-Kaibab, contemporary climate used to model forest growth and regeneration was based on downscaled climate normals from 1961-1990 [82]. Climate change factors spanned gradients of temperature and aridity projected for the southwestern US from Warm-Dry (based on the CCSM4 CMIP5 climate model [85] for the moderate emissions scenario RCP 4.5 [86,87]) to Hot-Arid (from the HadGEM2-ES CMIP5 climate model [88] for the high emissions scenario RCP 8.5). In FireBGCv2 data for both climate factors were acquired from the NASA Earth Exchange [89] for an 800-meter grid-cell coincident with the Jemez Springs weather station, then delta-downscaled for the period 2006-2009 by applying offsets derived from the slopes of linear regressions for individual seasons per weather year to the longest available Jemez station daily weather stream, 1954-2006. The delta method is a straightforward downscaling method that has a high level of climate realism desirable in future impact studies $[90,91]$. Future weather streams were then extrapolated to individual ecological sites as above. For LANDIS-II-Kaibab, climate change factors for vegetation dynamics were incorporated into C-FVS simulations. Site-specific growth and regeneration parameters for individual species were produced via downscaled climate surfaces available from the C-FVS webpage (http://charcoal.cnre.vt.edu/climate/customData/). Climate change factors for fire dynamics were incorporated into the daily fire weather data through the delta method. Adjusted fire weather data was then used to estimate fuel moisture inputs for fire modeling. Climate projections used for both the vegetation dynamics and fire dynamics were available at 30 year intervals, but we estimated intermediate values at 10 year intervals using linear interpolation (for more detail see Supplement 1 ).
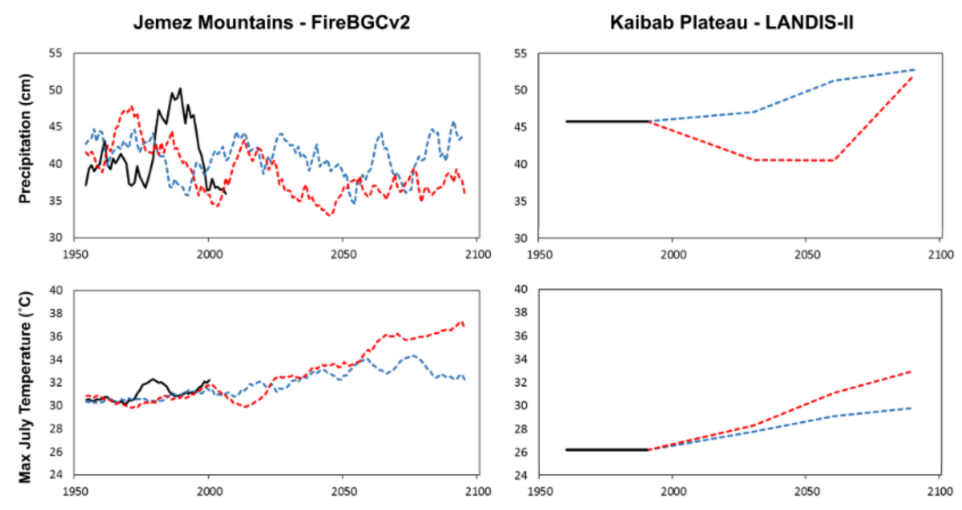

- Observed ----RCP 4.5 (Warm-Dry) ----RCP 8.5 (Hot-Arid)

Figure 2. Annual precipitation $(\mathrm{cm})$ and maximum July temperature $\left({ }^{\circ} \mathrm{C}\right)$ for Contemporary (solid black lines), Warm-Dry (CMIP5/CCSM4, RCP 4.5, dashed blue lines), and Hot-Arid (CMIP5/ HadGEM2-ES, RCP 8.5, dashed red lines) climate factors for FireBGCv2-Jemez and LANDIS-II-Kaibab simulation models. 
Management factors (Table S1) were derived from available prescriptions and burn plans for the study areas $[16,92]$ refined with input from southwestern managers. All management factors included wildfire suppression at a level consistent with current policy and implementation, simulated as a randomly extinguished $90 \%$ of annual ignitions in FireBGCv2-Jemez or modeled as a function of the modern fire size distribution in LANDIS-II-Kaibab. We modeled treatments of Suppression Only, Business as Usual (BAU), representing current treatments in ponderosa pine and dry mixed conifer forests of the study regions, a three-fold annual increase over BAU treatment area (3xBAU), and a six-fold annual increase over BAU (6xBAU). The BAU treatment was applied to $1.5 \%$ of the areal extent of the ponderosa pine site and $1.5 \%$ of the dry mixed conifer site annually, with a combination of thinning followed by prescribed fire $(0.75 \%)$ and prescribed fire only $(0.75 \%)$ in each site, corresponding to a 67-year landscape treatment rotation. Treatment rotations for 3xBAU and 6x BAU were 22 years and 11 years, respectively, corresponding to larger annual treatment areas (Figures 3 and 4). Treatments were applied each year to stands that met specified criteria (Table S1), regardless of whether they were treated in previous years.

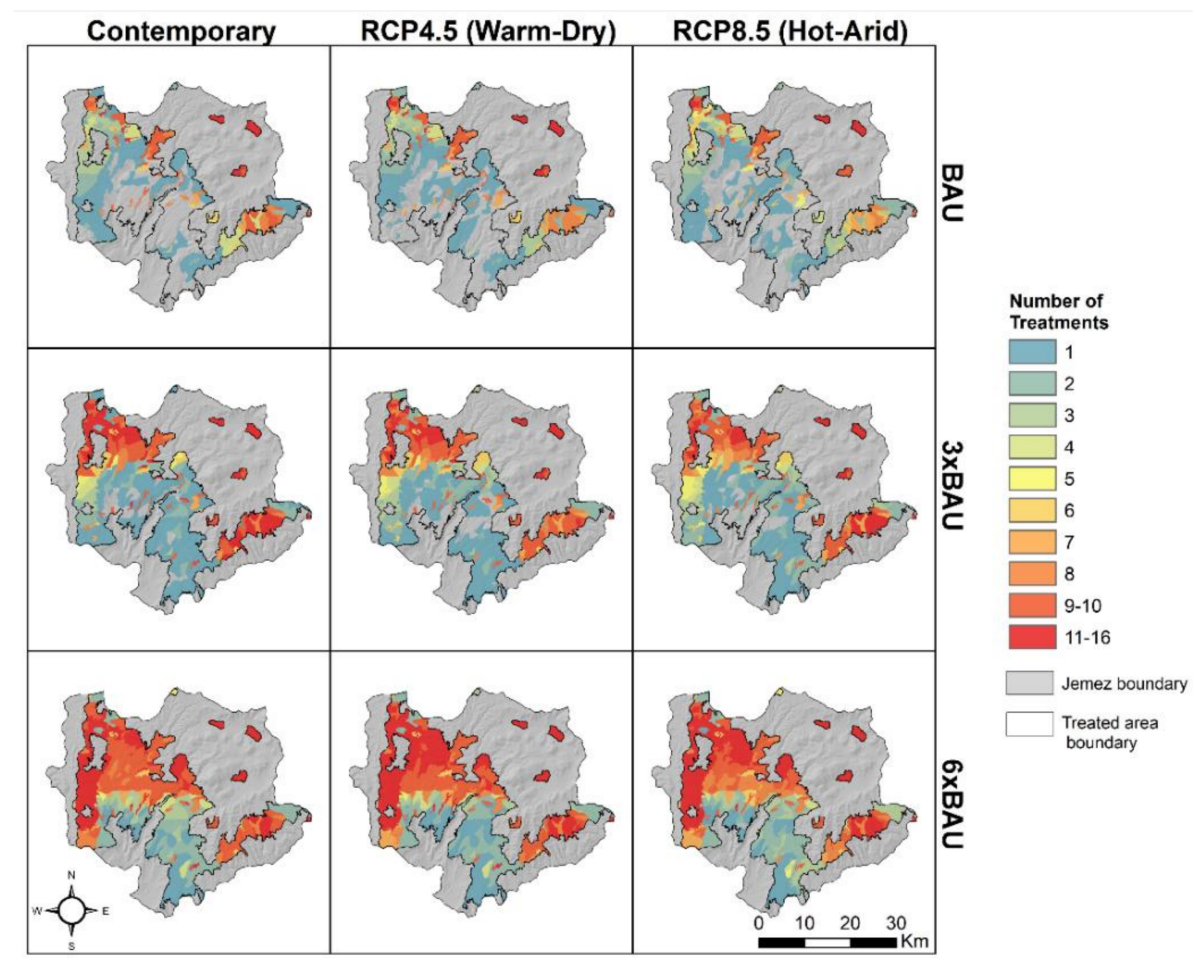

Figure 3. FireBGCv2-Jemez cumulative treated area and number of treatments per stand for the 100-year simulation period in managed forests of ponderosa pine and dry mixed conifer. All treatments are thinning followed by prescribed fire or prescribed fire only for business as usual (BAU) scenarios (1.5\% treated annually, 76-year treatment rotation), three-fold increase in BAU (3xBAU, 22-year treatment rotation) scenarios, and six-fold increase in BAU (6xBAU, 11-year treatment rotation) scenarios for contemporary climate and two climate change factors. 


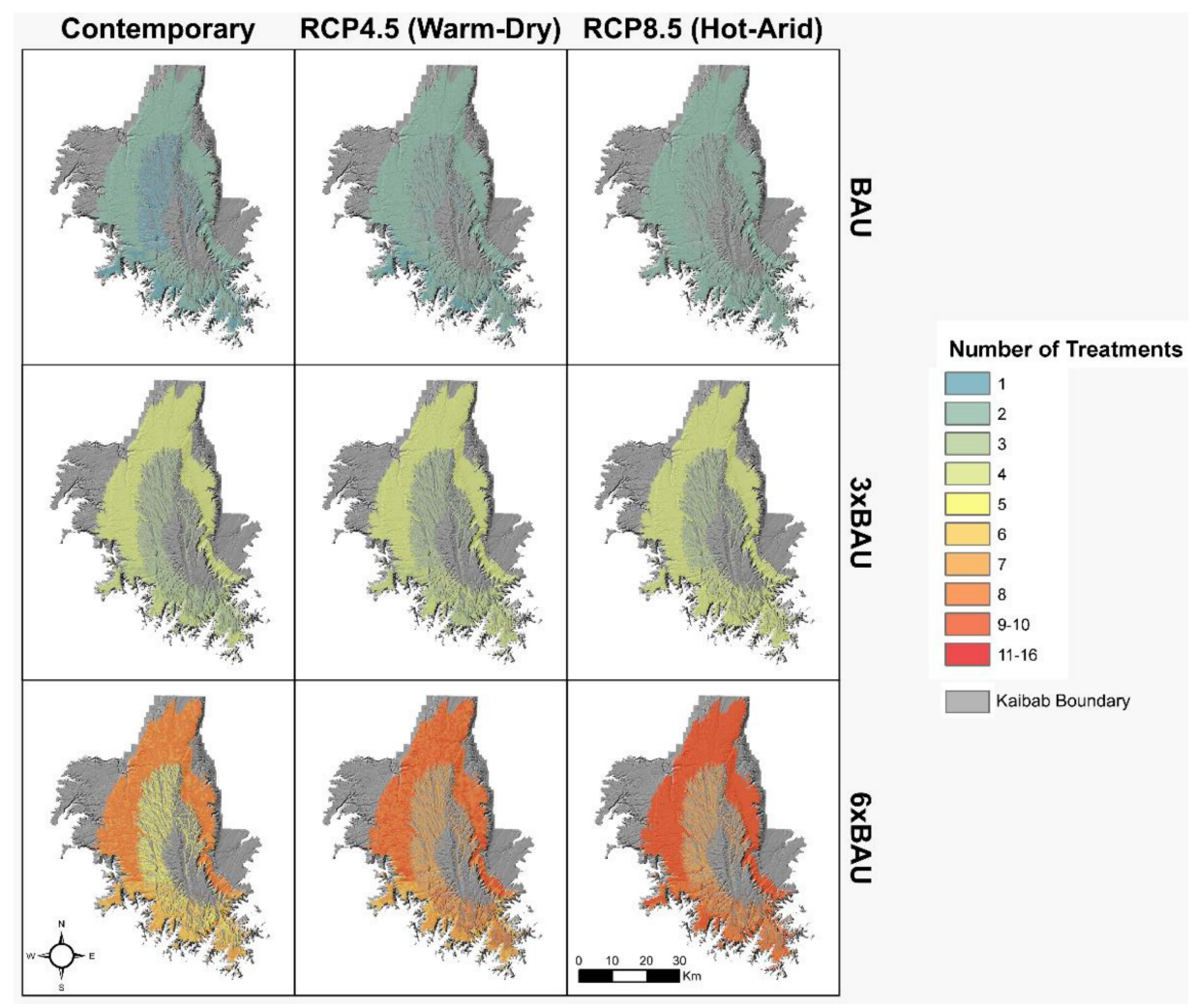

Figure 4. LANDIS-II-Kaibab cumulative treated area and number of treatments per stand for the 100-year simulation period for LANDIS-II-Kaibab in managed forests of ponderosa pine and mixed conifer. All treatments are thinning followed by prescribed fire or prescribed fire only for business as usual (BAU) scenarios (1.5\% treated annually, 76-year treatment rotation), three-fold increase in BAU (3xBAU, 22-year treatment rotation) scenarios, and six-fold increase in BAU (6xBAU, 11-year treatment rotation) scenarios for contemporary climate and two climate change factors.

\subsection{Model Responses and Analysis}

We used a suite of fire regime and ecosystem metrics to evaluate the impacts of climate and management (Table 1), focusing our analysis on the combined 77,489 ha (FireBGCv2-Jemez) or 155,439 ha (LANDIS-II-Kaibab) area of ponderosa pine and mixed conifer sites in which management treatments were implemented. Variables were produced at annual time steps (FireBGCv2) or every five years (LANDIS-II), and were summarized across scenario replicates for each time step.

High-severity wildfires were identified as those for which tree mortality was greater than $70 \%$ of the pre-fire canopy (FireBGCv2-Jemez) [93] or as wildfires for which greater than $50 \%$ of the crown burned (LANDIS-II-Kaibab). For wildfire area burned (total wildfire area burned or high-severity wildfire area burned), we produced boxplots as measures of the central value (median) and variability (25th and 75th percentiles), calculated for the pool of all replicates and all years for each scenario (FireBGCv2) or all replicates (LANDIS-II). Maps of fire return intervals (FRI) show the mean point FRI across replicates, where FRI for each replicate is the number of simulation years/total number of simulated fires calculated for each pixel. Prescribed fires were not included in analyses. Ecosystem metrics, computed for individual stands within ecological sites, included biomass, vegetation composition calculated as dominant species by biomass, and species structural stage (FireBGCv2) or age class (LANDIS-II). We plotted proportional species composition, structural stage, and age class as mean occupancy per species, structural stage and age class across replicates, and basal area $\left(\mathrm{BA}, \mathrm{m}^{2} / \mathrm{ha}\right.$ ) or biomass $\left(\mathrm{g} / \mathrm{m}^{2}\right)$ as time series plots of the replicate median and $25 \mathrm{th}$ and 75th percentiles of BA summed for all trees. 
Table 1. Fire regime and ecosystem metrics tracked for FireBGCv2-Jemez and LANDIS-II-Kaibab models. Metrics are similar between models, but note differences in calculations of forest biomass, forest structure, and high-severity wildfire area burned that reflect differences in model mechanics.

\begin{tabular}{|c|c|c|}
\hline & FireBGCv2-Jemez & LANDIS-II-Kaibab \\
\hline \multicolumn{3}{|c|}{ FIRE REGIME METRICS } \\
\hline Point fire return interval & $\begin{array}{l}\text { No. of simulation years/total number of } \\
\text { wildfires per pixel }\end{array}$ & $\begin{array}{l}\text { No. of simulation years/total number of } \\
\text { wildfires per pixel }\end{array}$ \\
\hline Area burned & Area of all wildfires (ha) & Area of all wildfires (ha) \\
\hline High severity area burned & $\begin{array}{l}\text { Area of all wildfires with tree mortality } \\
\qquad>70 \% \text { (ha) }\end{array}$ & $\begin{array}{l}\text { Area of all fires with }>50 \% \text { crown } \\
\text { fraction burned (ha) }\end{array}$ \\
\hline \multicolumn{3}{|c|}{ ECOSYSTEM METRICS } \\
\hline Vegetation composition & Proportional species biomass (\%) & Proportional species biomass (\%) \\
\hline Forest structure & Proportional species structural stage a (\%) & Proportional species age class ${ }^{b}(\%)$ \\
\hline Forest production & Basal area by species $\left(\mathrm{m}^{2} / \mathrm{ha}^{-1}\right)$ & Biomass by species, $\mathrm{g} / \mathrm{m}^{-2}$ \\
\hline
\end{tabular}

\section{Results}

\subsection{Fire Regime Metrics}

\subsubsection{Fire Return Interval}

FireBGCv2-Jemez fire return intervals decreased (wildfire frequency increased) for Warm-Dry and Hot-Arid climates relative to Contemporary climate for each management scenario (i.e., comparing climate impacts across all Suppression Only scenarios) (Figure 5). Fires were more frequent under progressively more severe drought conditions that increased the probability of ignition and fuel flammability, especially at lower elevations where fire return intervals were several decades shorter than for more moderate climates. As others have reported, fire suppression resulted in a fire deficit relative to historical reference conditions for dry southwestern forests [94,95], in which all simulated fire return intervals were substantially longer than reconstructed intervals of five to 12 years in ponderosa pine-dominated sites and 10 to 14 years in dry mixed conifer sites [41,43-45]. Management treatments had little effect on fire frequency for Contemporary climate (i.e., little difference between the Suppression Only scenario and BAU, 3xBAU, or 6xBAU) (Figure 5). Under Hot-Arid climate, fires were less frequent for 3xBAU and 6xBAU than for Suppression Only or BAU as the result of cumulative impacts of treatments and severe drought conditions on fuel availability, reducing fuel biomass to below the $0.05 \mathrm{~kg} / \mathrm{m}^{2}$ threshold required for successful fire ignition and spread in FireBGCv2.

LANDIS-II-Kaibab fire return intervals showed little to no change in response to climate, while management had a clear influence on fire frequency (Figure 6). Fires were most frequent for the Suppression Only management scenarios, with the shortest fire intervals of 30-40 years concentrated in large areas of contiguous low elevation ponderosa pine forest on the northern half of the plateau. Fuel treatments lengthened fire return intervals. The 3xBAU and 6xBAU treatments increased fire return intervals beyond 90 years for much of the study landscape. Due to the influence of fire suppression, fire return intervals under all scenarios (35-313 years) were longer than historical fire return intervals of six to nine years in ponderosa pine forests and seven to 31 years in mixed conifer forests $[53,96]$. 


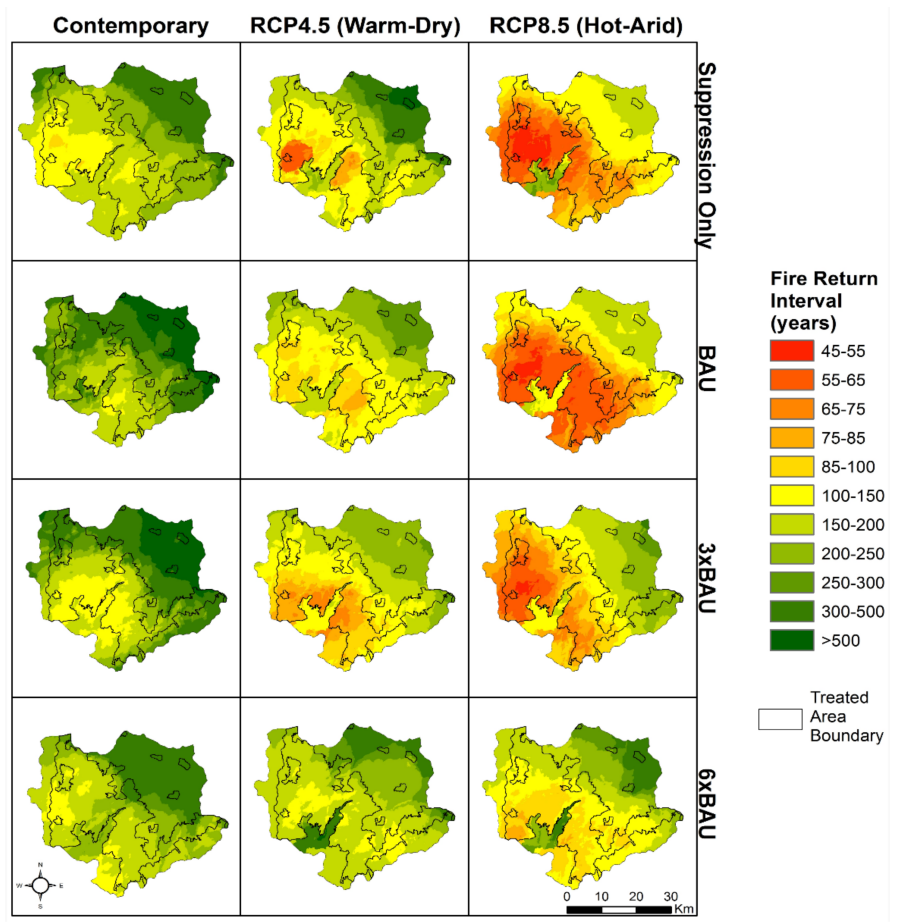

Figure 5. FireBGCv2-Jemez point fire return intervals (wildfires only; prescribed fires excluded). Scenarios are factorial combinations of management (Suppression Only; BAU, 76-year treatment rotation; 3xBAU, 22-year treatment rotation; 6xBAU, 11-year treatment rotation) and climate (Contemporary; Warm-Dry; Hot-Arid).

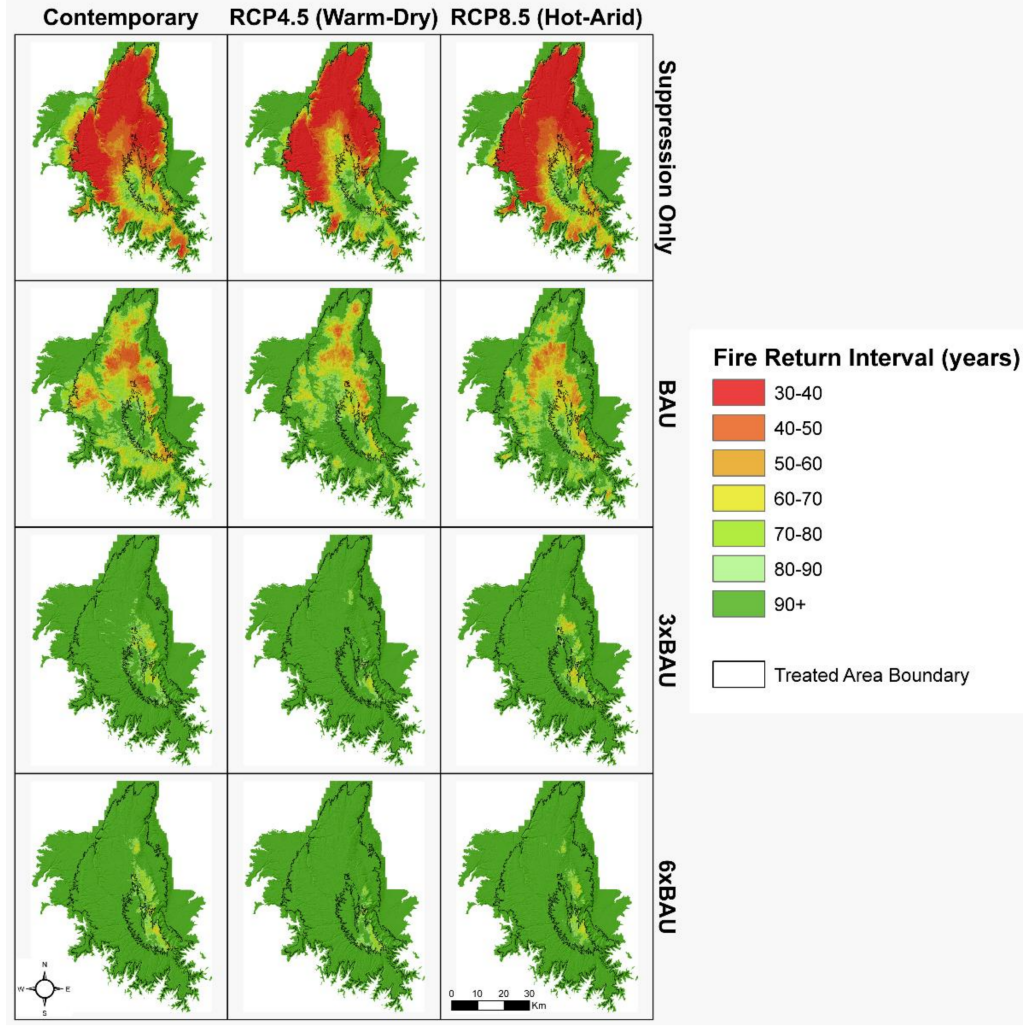

Figure 6. LANDIS-II-Kaibab fire return intervals (wildfires only; prescribed fires excluded). Scenarios are factorial combinations of management (Suppression Only; BAU, 76-year treatment rotation; 3xBAU, 22-year treatment rotation; 6xBAU, 11-year treatment rotation) and climate (Contemporary; Warm-Dry; Hot-Arid). 


\subsubsection{Wildfire Area Burned}

FireBGCv2-Jemez annual area burned increased with Warm-Dry and Hot-Arid climates relative to Contemporary climate (Figure 7a, Table S2). Median annual area burned was a small portion of the total area of dry managed forest, ranging from less than 1000 ha $(<1.5 \%$ of dry managed forest area) under Contemporary climate to over 2000 ha ( $>2.5 \%$ ) for Hot-Arid climate, but among some replicate-years, about 3000 to 5000 ha (five to ten percent, Contemporary climate) or about 6000 to 15,000 ha (seven to 19 percent, Warm-Dry and Hot-Arid climates) of dry forested area burned annually, with outlier years in which much or all of the entire $\sim 80,000$ ha dry forested area burned (Table S2, Figure 7a). This outcome is consistent with projections of climate-driven increases in area burned in the western US, particularly those in which a small fraction of fires ("megafires") become very large despite fire suppression efforts [21,32,97,98]. Management impacts on annual area burned varied with climate (Figure 7a). For Contemporary and Warm-dry climates, treatments increased annual area burned proportionally to management intensity (Suppression Only, BAU, 3xBAU) because thinning and prescribed fire treatments produced fuels that easily carry fire; i.e., were a positive feedback to fire (but 6xBAU treatments were sufficiently frequent and extensive to limit burnable fuels and reduce area burned). For Hot-Arid climates, annual area burned decreased with management intensity (Suppression Only, BAU, 3xBAU, 6xBAU), because treatments in combination with altered climate suppressed fuel production.

LANDIS-II-Kaibab area burned did not differ between the Contemporary climate scenario and the Warm-Dry or Hot-Arid climates (Figure 8a, Table S3). The consistency in area burned for all climate factors within Suppression Only scenarios indicates that climate had minimal influence. As discussed above, wildfire was most prevalent in the Suppression Only scenarios, where median area burned ranged from 3600 to 4400 ha (2.3 to $2.9 \%$ of dry managed forests). The BAU treatments only slightly reduced area burned ( 2600 ha to $3200 \mathrm{ha}$ ) compared to Suppression Only. The enhanced treatment rates 3xBAU and 6xBAU notably reduced the average annual area burned (700 to 1200 ha and 500 to 700 , respectively). The benefits of doubling the treatment rate from $3 x$ to $6 x B A U$ were limited, except for a reduction in the number of outlier years under the Hot-Arid scenario. However, exceptionally large fire years (outliers) may have outsized impacts on ecosystem function and recovery, justifying higher treatment rates.

\subsubsection{High-Severity Wildfire Area Burned}

FireBGCv2-Jemez median annual high-severity area burned (fires that resulted in $>70 \%$ tree mortality in stands) was small (less than 300 ha, or less than one percent of the total area of dry managed forest), but in some replicate-years, as much as 1700 ha (about two percent, Contemporary climate) or 5000 ha (about seven percent, Hot-Arid climate) of dry forested area burned annually at high severity (Figure $7 \mathrm{~b}$, Table S2). Outlier years under Hot-Arid climates burned more than $75 \%$ of the dry forested area $(60,000 \mathrm{ha})$ at high severity (Figure $7 \mathrm{~b}$ ), high-severity mega-fires that were much larger than those of the pre-European reference period [99]. There was no clear impact of management on median high-severity annual area burned; however, increasing treatment intensity reduced the upper range of high-severity burned area under Hot-Arid climate (Figure $7 \mathrm{~b}$ ). Management treatments had no effect on the extreme high-severity fire (outlier) years in the Hot-Arid climate scenarios.

Consistent with the previous results for the LANDIS-II-Kaibab simulations, management, not climate, was the primary influence on high-severity area burned. The area of high-severity fire declined considerably under the enhanced treatments (Figure 8b, Table S3). For the Hot-Arid climate and Suppression Only scenario, the high-severity fire rotation was 128 years for managed forest. The BAU, 3xBAU, and 6xBAU reduced this to 184, 526, and 3337 years, respectively. The rotation for the 3xBAU most closely aligns with a historical high-severity fire rotation of 528 years reconstructed in mixed conifer forests on the Kaibab Plateau [55]. Reductions in the area of high-severity fire could be particularly important in a changing climate, as forest turnover can be a catalyst for type changes $[100,101]$. 
(a) All wildfires

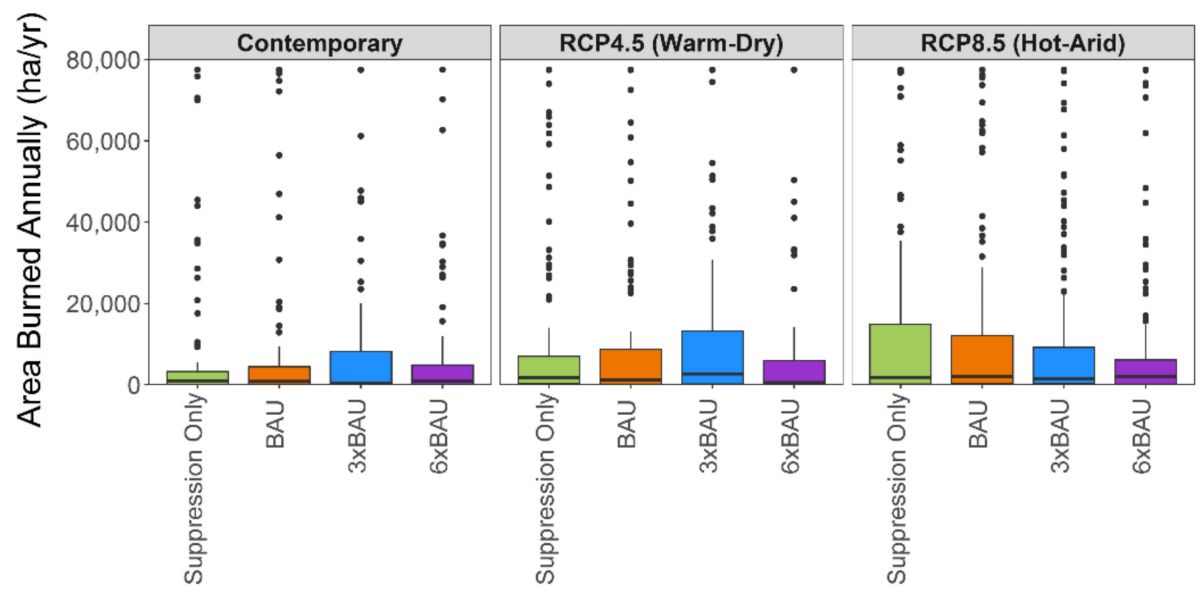

(b) High severity wildfires

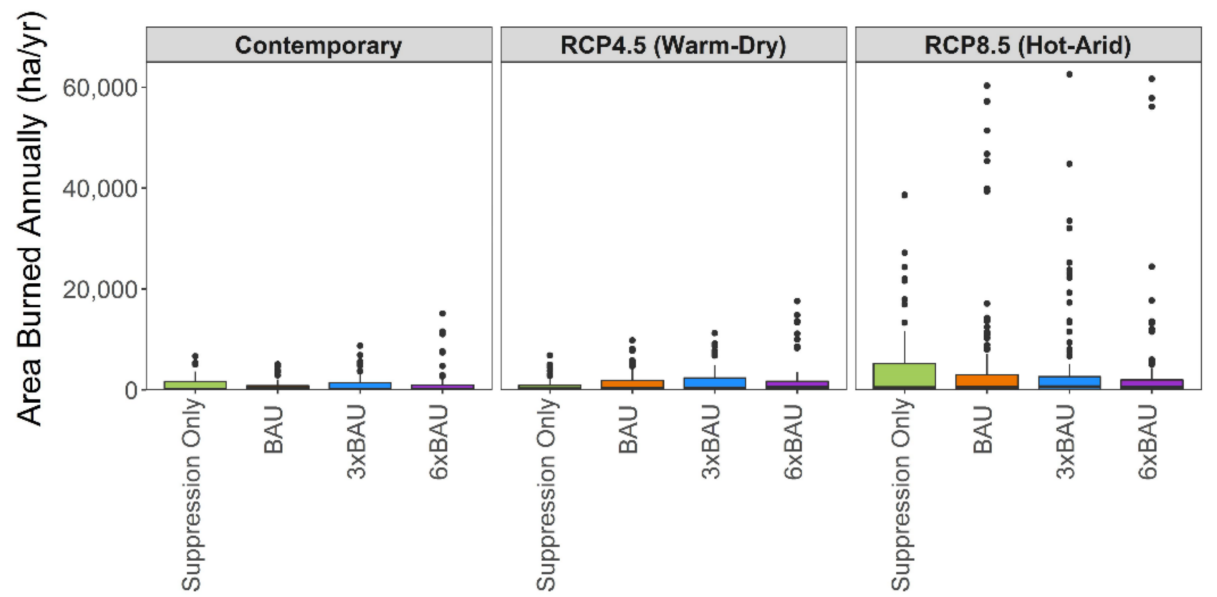

Figure 7. FireBGCv2-Jemez wildfire area burned annually (ha) in ponderosa pine and dry mixed conifer sites in (a) wildfires of all types and (b) high-severity wildfires (tree mortality $>70 \%$ ) for factorial combinations of management (Suppression Only; BAU, 76-year treatment rotation; 3xBAU, 22-year treatment rotation; 6xBAU, 11-year treatment rotation) and climate (contemporary; Warm-Dry; Hot-Arid). Boxplots show median, 25th, and 75th percentile wildfire area burned and outliers calculated for the pool of all replicates and all years for each scenario. The combined area of ponderosa pine and dry mixed conifer sites is 77,489 ha. 
(a) All wildfires

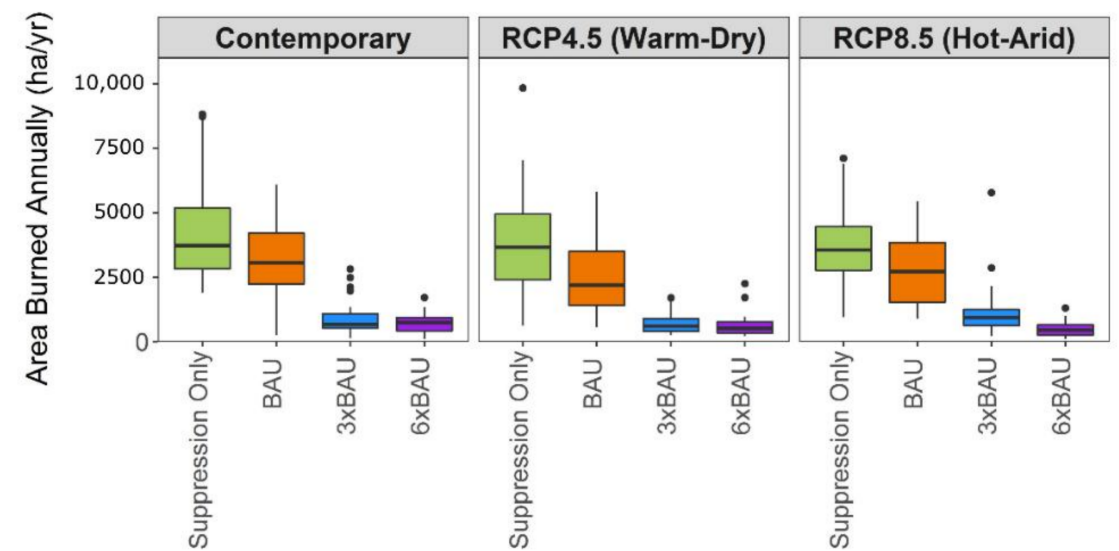

(b) High severity wildfires

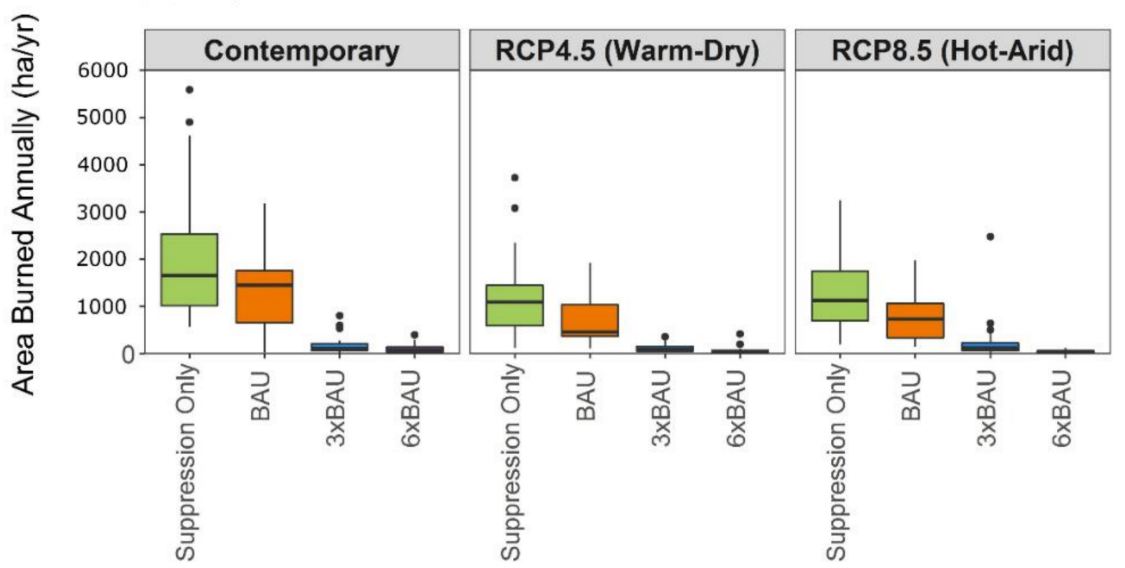

Figure 8. LANDIS-II-Kaibab wildfire area burned annually (ha) in ponderosa pine and dry mixed conifer sites for (a) wildfires of all types and (b) high-severity wildfires ( $>50 \%$ of crown burned) for factorial combinations of management (Suppression Only; BAU, 76-year treatment rotation; 3xBAU, 22-year treatment rotation; 6xBAU, 11-year treatment rotation) and climate (Contemporary; Warm-Dry; Hot-Arid). Boxplots show median area burned, 25th and 75th percentiles, and outliers among replicates and fire years for each scenario. The combined area of ponderosa pine and dry mixed conifer sites is 155,439 ha.

\subsection{Ecosystem Responses}

\subsubsection{Forest Composition}

For FireBGCv2-Jemez, Hot-Arid climate triggered a conversion of ponderosa pine forests to shrublands and woodlands dominated by Gambel oak, piñon pine, and juniper (Figure 9a). Conversion occurred ca AD 2075, corresponding to the hottest and driest period of future climate simulated in FireBGCv2-Jemez (Figure 2). Woodland expansion (but not shrub expansion) was somewhat mediated by management treatments: 3xBAU and 6xBAU reduced the proportion of piñon pine and juniper via thinning treatments that targeted smaller bole diameters characteristic of the species, and prescribed fire-caused tree mortality. In the dry mixed conifer site, where Gambel oak is not a significant component of the understory, aspen occupied an increasing proportion of the landscape as wildfires and area treated with prescribed fire increased (Figure 9b). This is consistent with aspen field studies documenting vigorous post-fire sprouting [41,102]; however, regeneration failed under Hot-Arid climate and co-occurring increased high severity burned area and more frequent fires. 
Coniferous species composition was relatively stable in the dry mixed conifer site over time and among climate-management scenarios (Figure 9b) as compared with the ponderosa pine site (Figure 9a). More frequent prescribed fire rotations and larger treatment areas of 3xBAU and 6xBAU scenarios slightly decreased the amount of forest dominated by Douglas-fir in middle elevations in favor of ponderosa pine (Figure 9a), somewhat mitigating 20th century trends of infill by shade tolerant Douglas-fir facilitated by anthropogenic fire exclusion $[19,77,103]$. Treatments increased the amount of aspen in the dry mixed conifer site for contemporary and Warm-Dry climates (Figure 9b), especially by the mid-21st century, when intensified 22-year (3xBAU) or 11-year (6xBAU) rotations frequently retreated previously managed stands (Figure 3). Rapid (within five years) post-fire regeneration of aspen has been documented in southwestern conifer forests [104]; however, prescribed fires that stimulated aspen growth also reduced piñon pines, a fire-sensitive species that is usually killed by fire [105].

LANDIS-II-Kaibab compositional changes were minimal during the 21st century. Throughout the simulation period, ponderosa pine was the dominant species on sites initially classified as ponderosa pine forest, regardless of climate or management scenario (Figure 10a). Gambel oak was most common in ponderosa pine forests under the Suppression Only scenario, likely due to the prevalence of high-severity fire in the absence of treatments, while oak declined in response to the BAU and enhanced BAU treatments that reduced high-severity area burned. In contrast to the Jemez results, Gambel oak did not increase under climate change scenarios, actually decreasing in response to Hot-Arid climate conditions. Dry mixed conifer forests generally shifted towards dominance of ponderosa pine in the Suppression Only management scenario (more high-severity fire) or the climate change scenarios (Figure 10b). Ponderosa pine is the most fire tolerant and drought tolerant of the tree species in the dry mixed conifer forests on the Kaibab Plateau $[54,106]$. Ponderosa pine increased in dominance at the expense of white fir, aspen, and to a lesser extent, Douglas-fir, which is also relatively tolerant to fire and drought. Under the Hot-Arid climate, white fir declined initially but began to recover later in the century with the application of fuel treatments. This recovery is likely due to increased precipitation during the last decades of the century under the Hot-Arid climate scenario. Although, as modeled, LANDIS-II-Kaibab compositional changes were limited, they will likely be substantial over longer time periods, indicated by the declining regeneration probability of initial overstory species that occurred in all forest types. For example, piñon pine and juniper were much more viable than ponderosa pine in the ponderosa pine forest type by the end of the century under the Hot-Arid scenario. This suggests that, given time (more than a 100-year simulation period), the model would show the replacement of ponderosa pine with piñon-juniper vegetation, as in FireBGCv2-Jemez. 
(a) Ponderosa pine

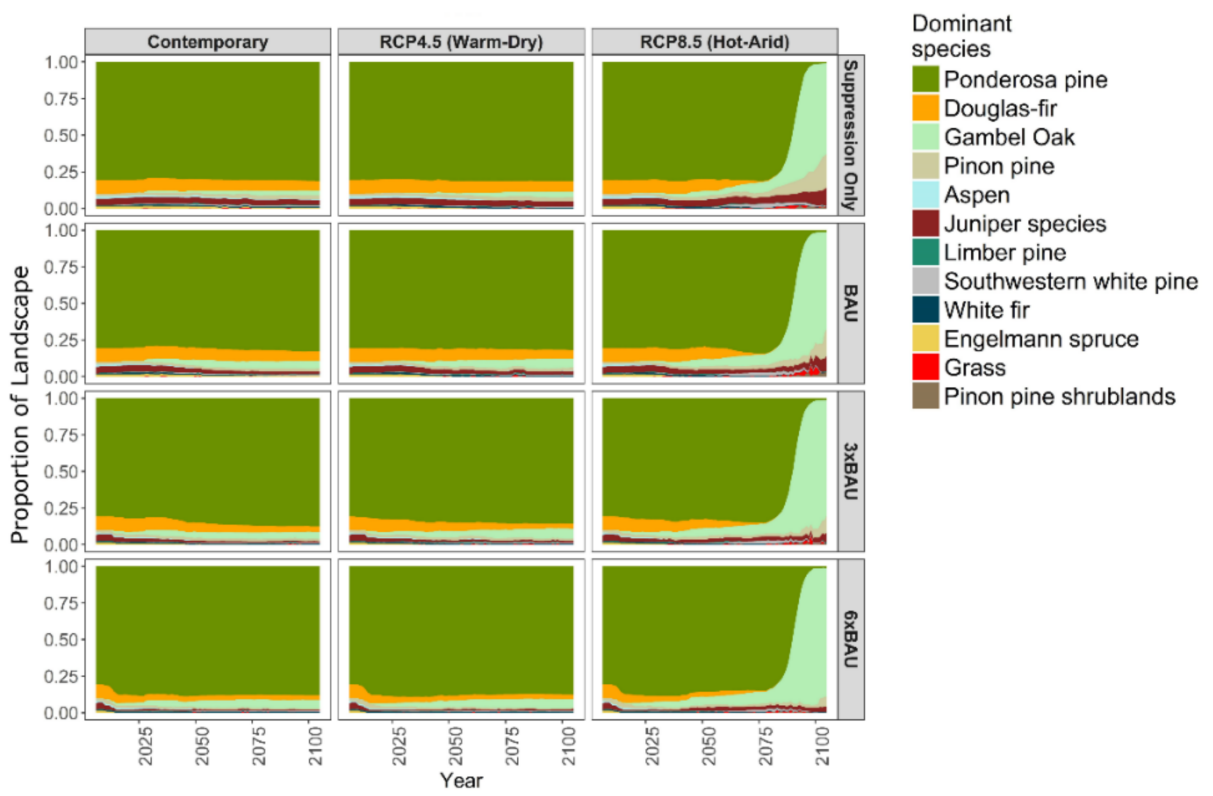

(b) Mixed conifer

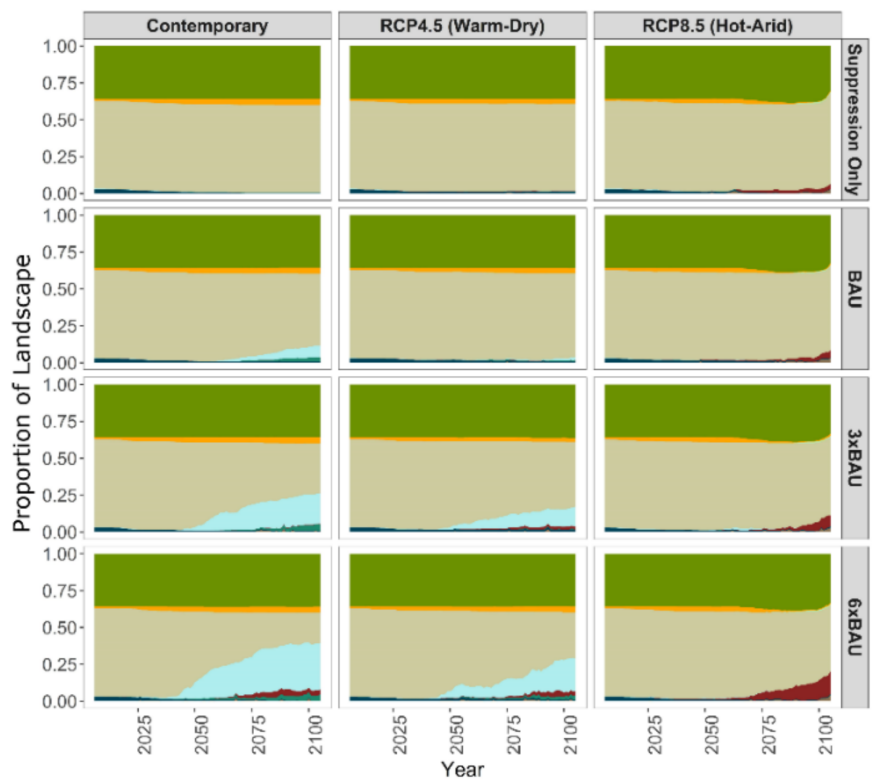

Figure 9. FireBGCv2-Jemez dominant vegetation by biomass for the ponderosa pine site (a) and dry mixed conifer site (b), represented as the proportional area within each site. Scenarios are factorial combinations of management (Suppression Only; BAU, 76-year treatment rotation; 3xBAU, 22-year treatment rotation; 6xBAU, 11-year treatment rotation) and climate (contemporary; Warm-Dry; Hot-Arid). The $x$-axes are simulation years and $y$-axes are proportional site area occupied by each species or life form. 
(a) Ponderosa pine

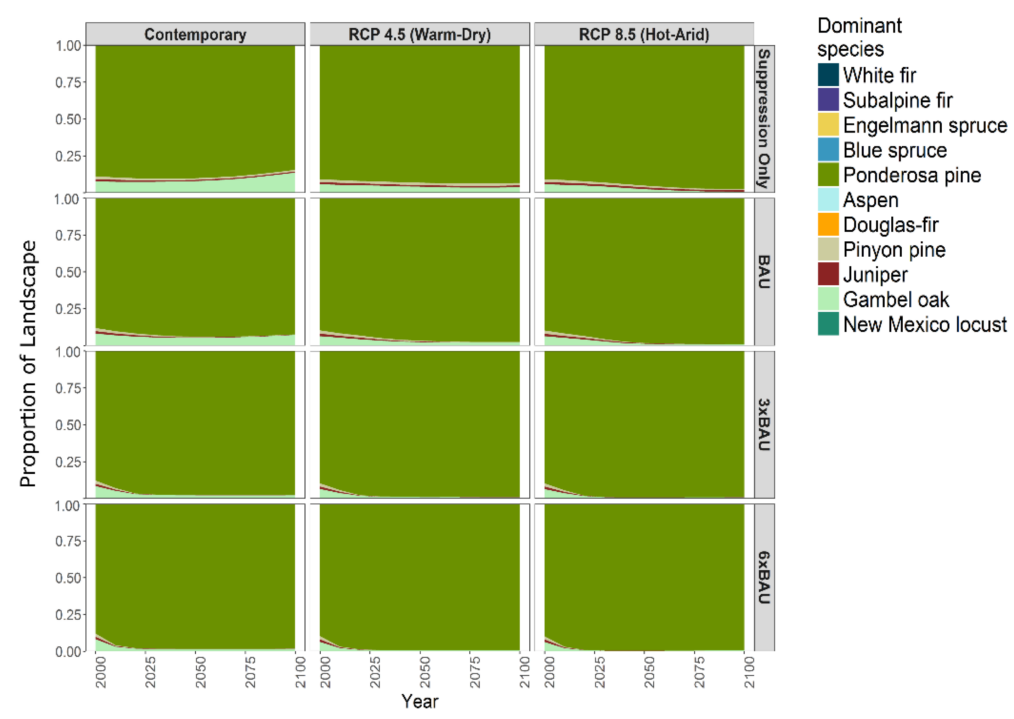

(b) Mixed conifer

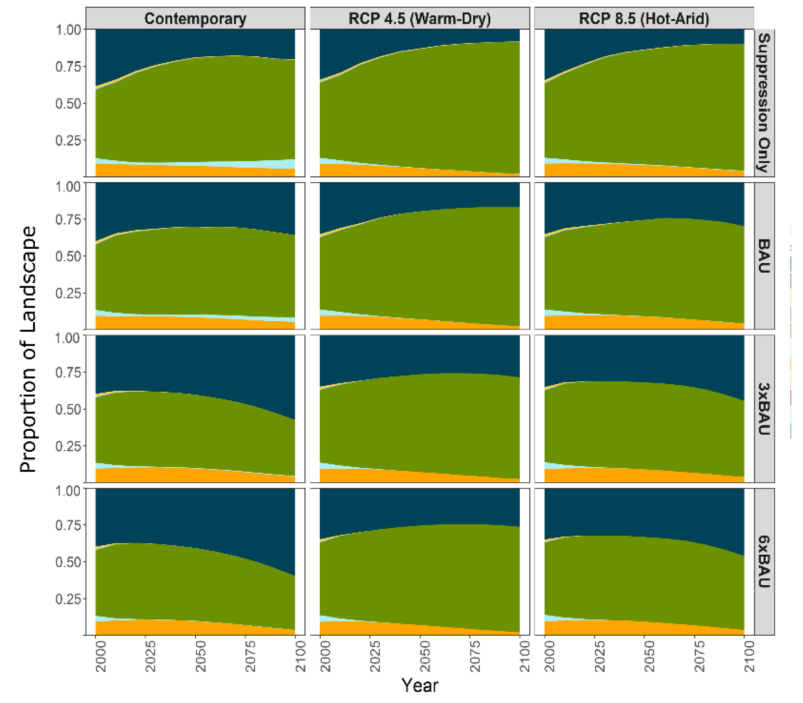

Figure 10. LANDIS-II-Kaibab dominant vegetation by biomass for the ponderosa pine site (a) and dry mixed conifer site $(\mathbf{b})$, represented as the proportional area within each site. Scenarios are factorial combinations of management (Suppression Only; BAU, 76-year treatment rotation; 3xBAU, 22-year treatment rotation; 6xBAU, 11-year treatment rotation) and climate (Contemporary; Warm-Dry; Hot-Arid). The $x$-axes are simulation years and $y$-axes are proportional site area occupied by each species or life form.

\subsubsection{Forest Structure}

For FireBGCv2-Jemez, Hot-Arid climate triggered a transition of the ponderosa pine site to stands dominated by immature, sapling stage trees (2 to $10 \mathrm{~cm} \mathrm{DBH)} \mathrm{ca} \mathrm{AD} 2075$ (Figure 11a), corresponding to the hottest and driest period of future climate simulated in FireBGCv2-Jemez (Figure 2). We attribute the disappearance of larger-sized trees to drought- and heat-induced tree mortality, with some additional losses due to high-severity fire. Such impacts of climate change on tree mortality have been well-documented at regional to global scales [107-110]. Although early-successional forests occupy a large proportion of the landscape, they are a relatively minor biomass component when compared with Gambel oak (Figure 11a). For Contemporary and Warm-Dry climates, the distribution of structural stages in the ponderosa pine site was stable through the 100-year simulation period and consistent with reference conditions for uneven-aged forests with a mix of small to large size classes [16]. Trees were predominantly 
of a mature stage (23 to $50 \mathrm{~cm} \mathrm{DBH),} \mathrm{with} \mathrm{smaller} \mathrm{proportions} \mathrm{of} \mathrm{saplings} \mathrm{(2} \mathrm{to} 10 \mathrm{~cm} \mathrm{DBH),} \mathrm{pole-sized}$ (10 to $23 \mathrm{~cm} \mathrm{DBH)}$, and large (50 to $100 \mathrm{~cm} \mathrm{DBH)} \mathrm{trees} \mathrm{(Figure} \mathrm{11a).} \mathrm{Saplings} \mathrm{increased} \mathrm{in} \mathrm{the} \mathrm{dry} \mathrm{mixed}$ conifer site under Warm-Dry and Hot-Arid climates ca. AD 2025 (Figure 11b), reflecting the increasing proportion of aspen (typically small in diameter [111]) and mortality and/or removal of trees that occurred with wildland fire and prescribed fires and fuels treatments.

LANDIS-II-Kaibab forest structure was impacted by declines in the regeneration of overstory species under the two climate change scenarios. Climate change driven regeneration failure was apparent from the age structure diagrams (Figure 12a,b), as proportional biomass shifted towards older cohorts during the middle of the century, when climate moved away from the regeneration niches of overstory species. Total biomass did not increase in older cohorts, but older trees gradually dominated the overall proportion of biomass due to a lack of regeneration moving new trees into younger age classes. The shift in age structure was less complete in the Warm-Dry scenario (Figure 12a,b) and in the dry mixed conifer stands for the Hot-Arid scenario (Figure 12b), where cooler and wetter conditions enabled some ponderosa pine regeneration.

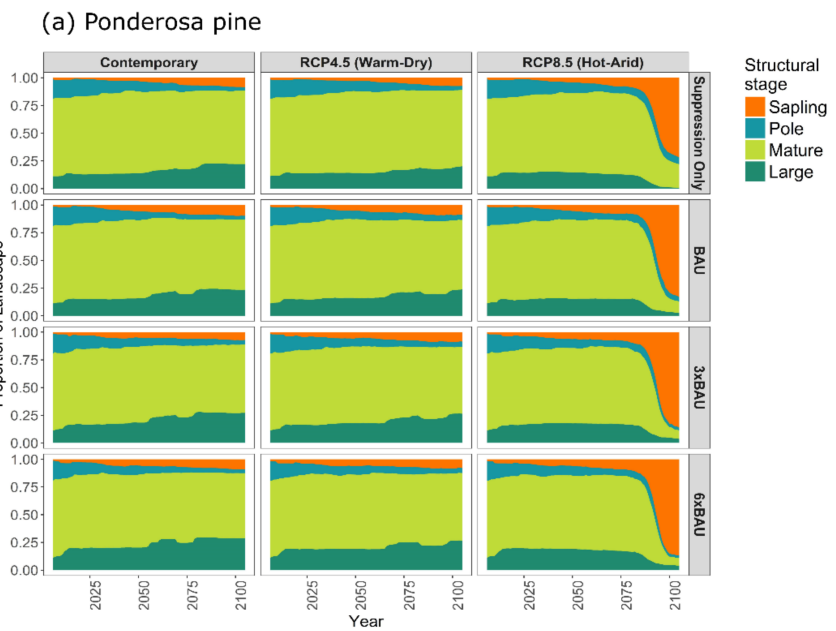

(b) Mixed conifer

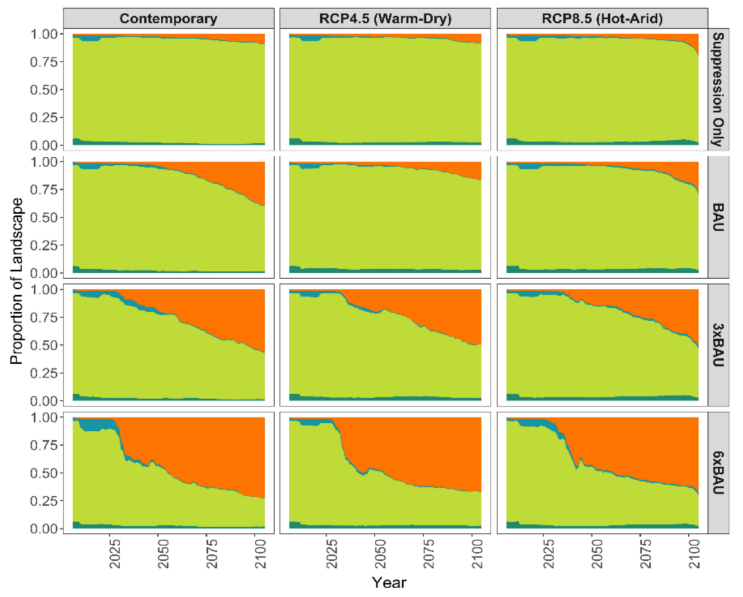

Figure 11. FireBGCv2-Jemez structural stage for the ponderosa pine site (a) and dry mixed conifer site (b). Scenarios are factorial combinations of management (Suppression Only; BAU, 76-year treatment rotation; 3xBAU, 22-year treatment rotation; 6xBAU, 11-year treatment rotation) and climate (Contemporary; Warm-Dry; Hot-Arid). Structural stages correspond to the following diameter classes $(\mathrm{cm}): 2 \leq$ saplings $\leq 10,10<$ pole $\leq 23,23<$ mature $\leq 50,50<$ large $\leq 100$, very large $>100$. The $x$-axes are simulation years and $y$-axes are proportional site area occupied by each structural stage. 
(a) Ponderosa pine

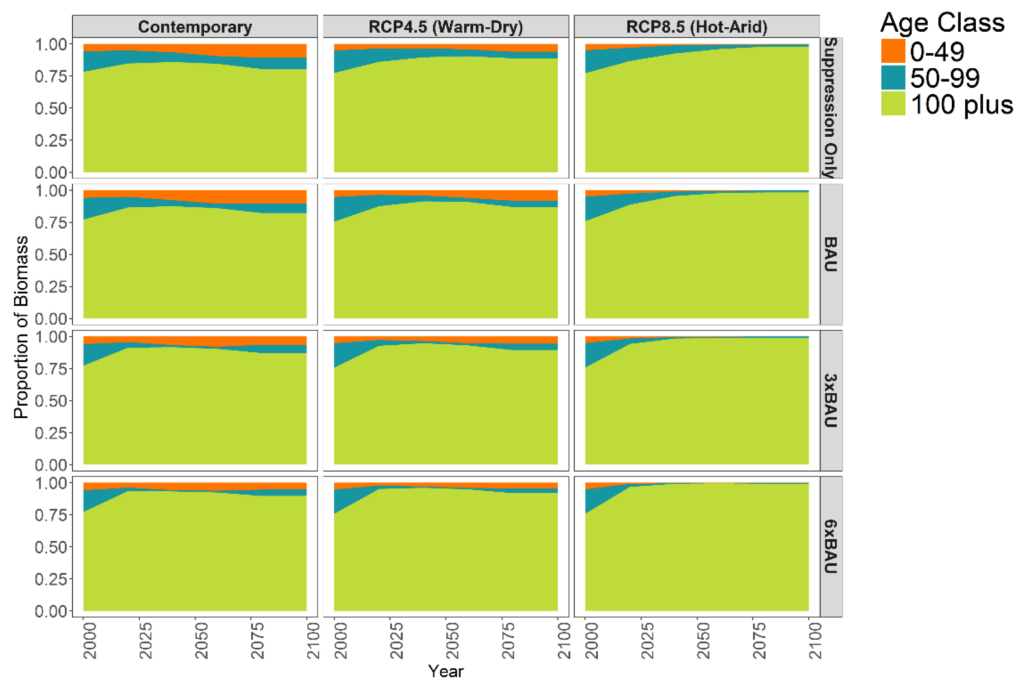

(b) Mixed conifer

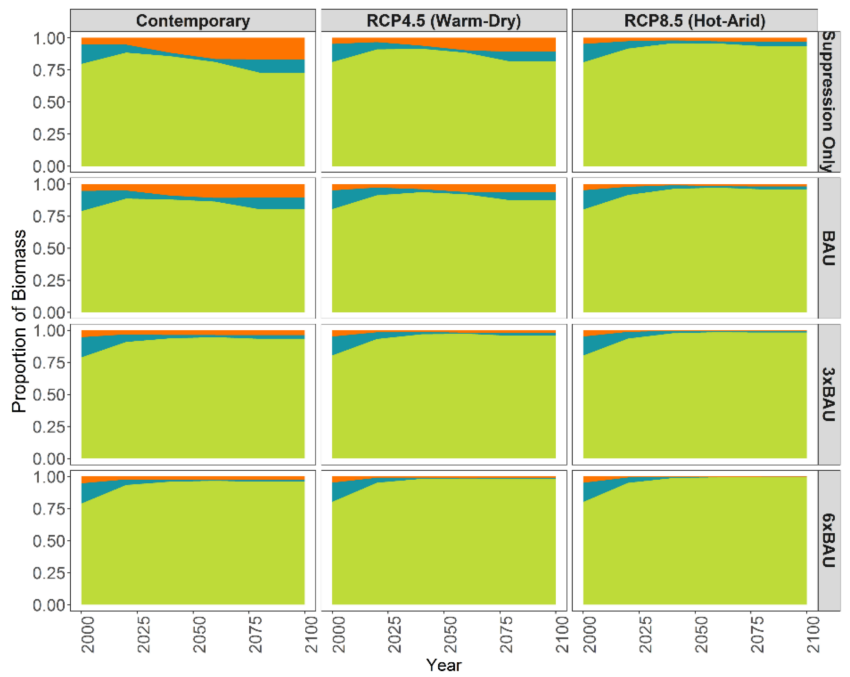

Figure 12. LANDIS-II-Kaibab proportion of biomass by age class for (a) ponderosa pine and (b) dry mixed conifer sites for factorial combinations of management (Suppression Only; BAU, 76-year treatment rotation; 3xBAU, 22-year treatment rotation; 6xBAU, 11-year treatment rotation) and climate (Contemporary; Warm-Dry; Hot-Arid). The $x$-axes are simulation years and $y$-axes are proportion of biomass in each age class. Age classes are young (0-49 years), mid (50-99 years), and old (100 plus years).

\subsubsection{Forest Production}

FireBGCv2-Jemez basal area (BA, sum of individual trees' cross-sectional area at $1.37 \mathrm{~m}$ above ground) for ponderosa pine and dry mixed conifer sites was initially similar to measurements of contemporary, fire-excluded southwestern dry conifer forests [77] (Figure 13), around $20 \mathrm{~m}^{2} / \mathrm{ha}$. Climate changes and management treatments decreased forest biomass relative to initial conditions. Warm-Dry climate and any of the four management factors maintained basal area well above pre-Euroamerican era estimates of around $13 \mathrm{~m}^{2} /$ ha $[16,77]$, although 3xBAU and 6xBAU treatments decreased basal area as compared with Suppression Only or BAU. Hot-Arid climate basal area decreased substantially, beginning early in the simulation period ca. AD 2025, with a further abrupt step change ca. AD 2075. By AD 2100, basal area was about 10 percent of its initial value, well below pre-settlement estimates. Loss of basal area occurred from a complex of ecological processes-tree mortality, regeneration failure, and compositional 
and structural shifts to shrublands or early successional forests-caused by climate stress, wildfires, management treatments, and changes in the distribution of bioclimatic space suitable for plant growth.

Biomass declines clearly illustrated the impact of climate on vegetation in the LANDIS-II-Kaibab landscape. Tree biomass decreased drastically under the Hot-Arid climate scenario (Figure 14). By the end of the century, average biomass in managed forests under the Hot-Arid scenario $\left(3881 \mathrm{~g} / \mathrm{m}^{2}\right)$ was well below historical estimates of pre-fire suppression biomass for ponderosa pine $\left(9850 \mathrm{~g} / \mathrm{m}^{2}\right)$ and dry mixed conifer $\left(7460 \mathrm{~g} / \mathrm{m}^{2}\right)$ on the Kaibab Plateau [52,112], indicating an overall forest decline and likely type change from forest to woodland or grassland. Biomass declines were driven by the failure of overstory species to regenerate under warmer and drier future climate conditions, as illustrated in the age structure shift to older cohorts. The absence of viable lower elevation species capable of replacing the declining overstory species delays biomass recovery and is also responsible for delays in compositional change. However, the drastic decline of forest biomass demonstrates that, despite the relatively static species composition, these forests are fundamentally altered by the Hot-Arid climate. Biomass declined slightly under the Warm-Dry scenario $\left(7467 \mathrm{~g} / \mathrm{m}^{2}\right)$ compared to Contemporary climate $\left(9798 \mathrm{~g} / \mathrm{m}^{2}\right)$, but remained within the historical pre-fire suppression estimates of biomass for ponderosa pine and dry mixed conifer forests referenced above. The enhanced treatment scenarios (3xBAU and 6xBAU) slightly increased the rate of biomass declines, suggesting that high rates of thinning and burning may accelerate forest decline under drastic climate shifts [113].

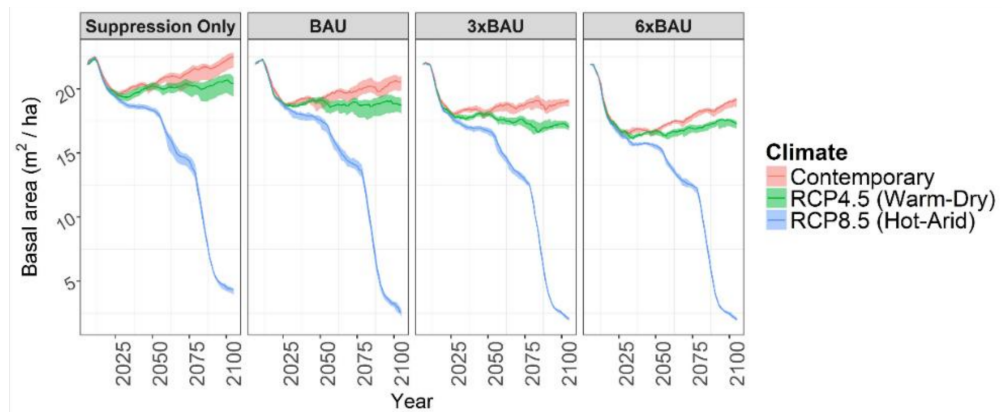

Figure 13. FireBGCv2-Jemez basal area $\left(\mathrm{m}^{2} / \mathrm{ha}\right)$ of ponderosa pine and dry mixed conifer sites. Scenarios are factorial combinations of management (Suppression Only; BAU, 76-year treatment rotation; 3xBAU, 22-year treatment rotation; 6xBAU, 11-year treatment rotation) and climate (Contemporary; Warm-Dry; Hot-Arid). Envelopes show median (darker line) and 25th and 75th percentiles (lighter shading) among replicates for each scenario.

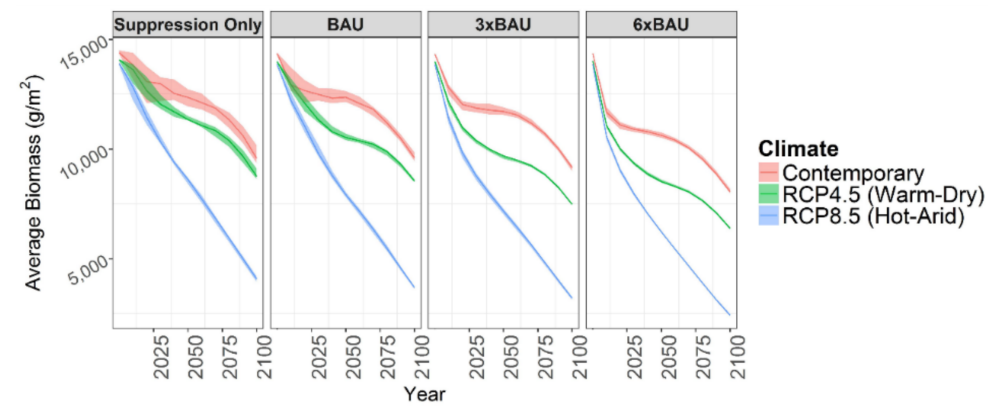

Figure 14. LANDIS-II-Kaibab average tree species biomass $\left(\mathrm{g} / \mathrm{m}^{2}\right)$ for ponderosa pine and dry mixed conifer sites. Scenarios are factorial combinations of management (Suppression Only; BAU, 76-year treatment rotation; 3xBAU, 22-year treatment rotation; 6xBAU, 11-year treatment rotation) and climate (Contemporary; Warm-Dry; Hot-Arid). Envelopes show median (darker line) and 25th and 75th percentiles (lighter shading) among replicates for each scenario. 


\section{Discussion}

\subsection{Will Climate Changes Cause Fundamental Changes in Southwestern Fire Regimes and Forests?}

Models did not produce consistent impacts of climate on fire regimes. For FireBGCv2-Jemez, wildfires were more frequent under Warm-Dry and Hot-Arid climates, and the Hot-Arid scenario resulted in an increase in median high-severity wildfire burned area and in episodic, high-severity "mega-fire" events. In contrast, climate had little impact on fire outcomes in LANDIS-II-Kaibab. Varying responses reflect fundamental differences in model mechanics (see below).

Our models were consistent in projecting a fundamental reorganization of ecosystem properties under the Hot-Arid climate scenario, and to a lesser extent, the Warm-Dry climate scenario. As modeled, the more extreme Hot-Arid climate is a "tipping point," driving biomass declines, shifts in forest structure, and compositional changes. Tipping points are critical thresholds at which even small perturbations radically and persistently reorganize system patterns or processes [114,115]. This fundamental reorganization of ecosystems aligns with previous modeling that incorporates climate change, fire, and vegetation interactions in temperate forests $[57,116]$, as well as conceptual models that identify shrublands as an alternative, stable state in dry conifer-shrub ecosystems catalyzed by interacting anthropogenic stressors (e.g., climate changes and altered fire regimes) that push systems past a tipping point $[117,118]$. Modeled forest to shrubland transformations are aligned with field studies; for example, a recent study in the Jemez Mountains attributes the presence of Gambel oak shrubfields to high-severity wildfire disturbances [118]. Oak shrubfields, once established, can be highly resilient to subsequent high-severity fire events $[45,117]$. Ecotonal shifts between ponderosa pine forests and piñon-juniper woodlands have also been documented in the southwest, in response to a severe drought in the 1950s [119] and more recent drought conditions [120]. From our results, we infer that dry forests of the Jemez, NM and Kaibab, AZ ecosystems-and, by extension, other dry forest ecosystems in the southwestern US - may be vulnerable to a type change from forest to shrubland or grassland. Persistent changes in these systems may be driven by (1) shifts in fire regimes due to changes in climate and fuel availability, type, and structure; and (2) climate-driven regeneration failure as ecosystems depart from optimal conditions for overstory tree species.

Ponderosa pine forests of the Jemez Mountains were more substantially altered by climate and wildfire than dry mixed conifer forests, which contain species of varying drought resistance and physiological tolerance and therefore exhibited a more stable response to changing climate conditions. This outcome provides support for the hypothesis that species diversity promotes functional resilience to climate perturbations [121,122]. This conclusion is further supported by comparing responses between the two landscapes. In the Jemez Mountains, the ponderosa pine (Figure 9a) and dry mixed conifer (Figure 9b) sites both contain a significant component of lower-elevation piñon and juniper species, with mature individuals providing propagules as soon as climate conditions shift to favor these species. In contrast, piñon and juniper species are largely missing from ponderosa pine and dry mixed conifer sites on the Kaibab Plateau (Figure 10a,b); therefore, these species must encroach from lower elevations. This recruitment mechanism is also apparent in compositional shifts and biomass recovery that occurred more rapidly in the wet mixed conifer and spruce-fir forests as compared to ponderosa pine forests on the Kaibab Plateau (data not shown). Contemporary wet mixed conifer and spruce fir forests include ponderosa pine, which remains viable at these sites throughout the climate changes of the next century. In forests, types where none of the current overstory species remain viable, delayed uphill movement of lower elevation species will likely exacerbate and lengthen biomass declines and increase the potential for persistent type changes where shrub or cheatgrass communities establish and resist future invasion by tree species [118,123]. Because our models did not include insect disturbance, which has been a significant cause of recent tree mortality in the southwestern US and particularly in piñon pines in the southwest [124], the role of piñon pine in maintaining tree cover and initiating forest recovery could be unrealistic. We hypothesize that if insect disturbance were included 
in the models, differential piñon mortality would shift woodland dominance to juniper species, which may or may not play a similar ecological role in woodland systems $[119,125]$.

\subsection{Will Current Management Approaches be Effective in Preventing Departures under Future Climates?}

Management treatments had little effect on ecosystem responses to climate change in FireBGCv2-Jemez and LANDIS-II-Kaibab. For both landscapes, the current management strategy (BAU scenarios) was consistently ineffective in preventing changes under future climate. Thinning and prescribed burning treatments at current application rates had little appreciable influence on area burned or high-severity area burned. At the stand scale, fuel treatments have been shown to be highly effective at reducing potential fire severity [126,127]. However, our modeling indicates that the current rate of application has little impact on wildfire outcomes at the landscape scale. The BAU scenarios were also ineffective in preventing biomass declines, shifts in age structure, and compositional changes under future climate. Targeted treatments may temporarily achieve objectives and protect high value landscape components. However, the central role of climate in driving forest changes through either mortality or regeneration failure suggests that the benefits of current treatments will likely be temporary.

\subsection{Do Shifting Climate and Fire Regimes Require Novel Management Approaches?}

Management strategies did not maintain current biomass, composition, or structure with changing climate. Although 3xBAU and 6xBAU treatments impacted wildfire regimes on the Kaibab landscape, they were ineffective at buffering or delaying the reorganization of forest ecosystems on either landscape. Intensified treatment scenarios (3xBAU and 6xBAU) slightly increased the rate of biomass declines, suggesting that high rates of thinning and burning may accelerate forest decline under drastic climate shifts [113]. The 6xBAU treatment strategy achieved treatment rotations of eleven years, the approximate historic fire rotation for ponderosa pine and dry mixed conifer forests, but increased areal extent and frequency of treatments alone was not an effective tool for preventing fundamental ecological shifts, especially under Hot-Arid climate. This result suggests that novel management approaches may be required to sustain forest landscapes or facilitate the adaptation of forests to changing climate and fire regimes $[33,35,36]$. For example, the planting of lower elevation species, adapted to warmer and drier conditions, could facilitate species migration, accelerating ecosystem recovery and reducing the depth of biomass declines [128,129].

\subsection{Model Influences on Outcomes}

Outcomes can differ across ecological models as the result of different model structures, initializing conditions, parameterization, and data inputs. Complex models are sensitive to a large number of factors (e.g., climate, weather, terrain) because they explicitly simulate the relevant underlying mechanistic processes. FireBGCv2 and LANDIS-II are highly complex models that mechanistically link climate, weather, and fuel patterns to fire frequency and area burned $[83,130]$. In FireBGCv2, fire regime characteristics are emergent model properties, determined by iterative climate and fire influences on fuel properties (type, amount, moisture) and live vegetation characteristics (e.g., bark thickness, canopy base height, DBH, vigor). Climate can serve as either a positive feedback to fire (e.g., warming temperatures increase landscape burnability by decreasing fuel moisture) or a negative feedback (e.g., drought conditions decrease burnabilty via reduction in biomass). In this study, the combination of larger areal extent of thinning and prescribed fire treatments, increased high-severity wildfire area burned, climate conditions unfavorable for tree recruitment and regeneration, and understory biomass production modeled for the Hot-Arid, 3xBAU and 6xBAU scenarios served as a negative feedback to fire frequency via reductions in fuel availability and connectivity $[94,103,131]$. In the LANDIS-II DFF extension, climate influences on area burned are partially restricted by the input of a user defined fire size or fire duration distribution. We used a fire duration distribution, which enables individual fires to increase in size in response to climate influences on fuel moisture and consequent fire spread 
rates. Therefore, individual fires should increase in size in response to a warmer and drier climate and potentially increase area burned. Yet, this model dynamic does not account for additional large fires that might be expected to escape suppression under a hotter and drier future. LANDIS-II simulations, in contrast to the FireBGCv2 simulations, also did not incorporate the direct influence of climate changes on the number of ignitions (e.g., fuel moisture influences on the likelihood of ignitions). However, the model does incorporate the indirect influence of climate-driven vegetation changes and subsequent changes in fuel conditions on the number of ignitions. Still, the missing link between direct impacts of climate on the number of ignitions represents an important limitation in the assessment of climate influences on future fire regimes in the LANDIS-II DFF extension as it is configured in this particular study, and it may explain the reduced sensitivity of the fire regime to climate. Ultimately, we did not produce consistent projections of future fire regimes, due to differences in model mechanics. However, despite their differences, models did produce consistent projections of substantially altered forest composition, structure, and biomass, suggesting a level of biotic reorganization that will affect management goals and strategies for southwestern landscapes.

Sources of uncertainty in model results come from input climate model data, which are inherently uncertain because climate change and the severity of its impacts depend on future emissions and mitigation measures. Additionally, global climate models (GCMs) may not accurately represent climate and weather at the regional and local scales, particularly concerning precipitation trends and climate oscillations that influence fire patterns [132-134]. The delta method used to locally downscale climate model inputs only accounts for changes to the mean climate signal, and not to shifts in synoptic-scale climate patterns outside of observed weather [90,135]. Finally, neither of our models included insects as a disturbance agent, although insect outbreaks are predicted to increase with warmer and drier climates [136,137]. Significant insect-caused tree mortality has already occurred in piñon pines in the Southwest [124], and insect disturbance, if modeled, could influence forest dynamics.

\section{Conclusions}

Although this study was not designed as a factorial model comparison (i.e., in which both models are developed for each landscape), similarities in the model results suggest common, regional-scale ecological inferences useful for understanding current and future climate, fire, and vegetation dynamics across southwestern forested ecosystems. Both models projected persistent compositional and structural changes in present-day dry conifer forests caused by climate changes and shifting fire patterns, particularly in ponderosa pine forests. We found resilience traits in dry mixed conifer forests in both model landscapes, and indications that ecotonal zones-for example, piñon-juniper ponderosa pine ecotone in the Jemez Mountains - can facilitate relatively rapid upslope movement of drought-adapted species into areas that have become too arid to support more mesic forests. Models produced dissimilar outcomes related to management and climate impacts on fire regimes, the result of inherent differences in model mechanics. However, both models captured cumulative, reciprocal interactions of climate, fires, and vegetation that highlight the complexity of fire-prone ecological systems in which key driving processes (e.g., climate) have both direct and indirect and short- and long-term influence on landscape patterns and processes.

Our results are compatible with recent papers that have identified the need for new strategies to promote the resilience of fire-prone forested ecosystems. Current and intensified management treatments simulated for FireBGCv2-Jemez and LANDIS-II-Kaibab did not prevent fundamental reorganization of the study landscapes under changing climates, suggesting that historical or present-day forest and fire regime characteristics may not be achievable management targets in the future. The design of novel management approaches will present two important challenges. First, it requires managers to reach a consensus on achievable objectives under future climate conditions, not based on historic reference conditions. Potential objectives could include the maintenance of functional types or ecosystem services, biomass conservation, carbon sequestration, the maintenance of key habitat types, or the conservation of species and genetic diversity [138]. Second, managers would need 
to begin implementing and experimenting with untested approaches that could produce unintended consequences. Modeling studies will be an important component of this process, helping to inform the selection of promising treatments and anticipate risks. However, ultimately, these approaches will require testing in actual landscapes, perhaps initially at smaller scales. This approach poses a difficult but critical path forward, requiring a dynamic, experimental land management framework that anticipates change, acknowledges that current systems have transformed or will transform away from historical references, and allows dynamic ecological processes to occur [139].

Supplementary Materials: The following are available online at http:/ /www.mdpi.com/1999-4907/9/4/192/s1, Supplement 1: Methods: The FireBGCv2 and LANDIS-II models, Table S1: Treatment parameters for FireBGCv2-Jemez and LANDIS-II-Kaibab modeling simulations. Results: Table S2: FireBGCv2-Jemez wildfire area burned, Table S3: LANDIS-II-Kaibab wildfire area burned.

Acknowledgments: This research was funded by the Joint Fire Science Program (project 15-1-03-26, Landscape Impacts of Fire and Climate Change in the Southwest: A Science-Management Partnership, "SW FireCLIME"), the National Science Foundation Coupled Natural and Humans Systems Program (project 1114898, Jemez Fire and Humans in Resilient Ecosystems, "FHiRE"), the Arizona Technology and Research Initiative Fund, and the USGS Land Change Science Program. We also received support from the JFSP Southwest Fire Science Consortium. The authors gratefully acknowledge the contributions of many collaborators including Bob Keane, USFS Rocky Mountain Research Station, for FireBGCv2 development; Casey Teske and Windy Bunn, National Park Service, Shaula Headwall, US Fish and Wildlife Service, and Dennis Carril, Craig Wilcox, and David Robinson, US Forest Service, for guidance on and suggestions for management inputs; other members of the SW FireCLIME team for their project contributions; and the large number of participants at several science-management workshops. We thank Larissa Yocum Kent and two anonymous reviewers for their valuable comments and Mary Whalen (USGS) for graphics assistance. Any use of trade names is for descriptive purposes only and does not imply endorsement by the US Government.

Author Contributions: R.L., W.F., and A.T. conceived of and designed the experiments; L.H. and W.F. performed the experiments and produced summary data and graphics; R.L. and W.F. analyzed the data and wrote the paper.

Conflicts of Interest: The authors declare no conflict of interest.

\section{References}

1. Case, M.J.; Lawler, J.J. Integrating mechanistic and empirical model projections to assess climate impacts on tree species distributions in northwestern North America. Glob. Chang. Biol. 2017, 23, 2005-2015. [CrossRef] [PubMed]

2. Danby, R.K.; Hik, D.S. Variability, contingency and rapid change in recent subarctic alpine tree line dynamics. J. Ecol. 2007, 95, 352-363. [CrossRef]

3. Hamann, A.; Wang, T. Potential effects of climate change on ecosystem and tree species distribution in british columbia. Ecology 2006, 87, 2773-2786. [CrossRef]

4. Kelly, A.E.; Goulden, M.L. Rapid shifts in plant distribution with recent climate change. Proc. Natl. Acad. Sci. USA 2008, 105, 11823-11826. [CrossRef] [PubMed]

5. Rehfeldt, G.E.; Crookston, N.L.; Warwell, M.V.; Evans, J.S. Empirical analyses of plant-climate relationships for the western United States. Int. J. Plant Sci. 2006, 167, 1123-1150. [CrossRef]

6. Dale, V.H.; Joyce, L.A.; McNulty, S.; Neilson, R.P.; Ayres, M.P.; Flannigan, M.D.; Hanson, P.J.; Irland, L.C.; Lugo, A.E.; Peterson, C.J. Climate change and forest disturbances. Bioscience 2001, 51, 723-734. [CrossRef]

7. Flannigan, M.; Stocks, B.; Wotton, B. Climate change and forest fires. Sci. Total Environ. 2000, 262, $221-229$. [CrossRef]

8. Gavin, D.G.; Hu, F.S. Spatial variation of climatic and non-climatic controls on species distribution: The range limit of tsuga heterophylla. J. Biogeogr. 2006, 33, 1384-1396. [CrossRef]

9. Bond, W.J.; Woodward, F.I.; Midgley, G.F. The global distribution of ecosystems in a world without fire. New Phytol. 2005, 165, 525-537. [CrossRef]

10. Krawchuk, M.A.; Moritz, M.A.; Parisien, M.A.; Van Dorn, J.; Hayhoe, K. Global pyrogeography: The current and future distribution of wildfire. PLoS ONE 2009, 4, e5102. [CrossRef]

11. Loehman, R.A.; Reinhardt, E.; Riley, K.L. Wildland fire emissions, carbon, and climate: Seeing the forest and the trees-a cross-scale assessment of wildfire and carbon dynamics in fire-prone, forested ecosystems. For. Ecol. Manag. 2014, 317, 9-19. [CrossRef] 
12. Turner, M.G.; Romme, W.H. Landscape dynamics in crown fire ecosystems. Landsc. Ecol. 1994, 9, 59-77. [CrossRef]

13. Heyerdahl, E.K.; Morgan, P.; Riser, J.P. Multi-season climate synchronized historical fires in dry forests (1650-1900), northern rockies, USA. Ecology 2008, 89, 705-716. [CrossRef] [PubMed]

14. Whitlock, C.; Shafer, S.L.; Marlon, J. The role of climate and vegetation change in shaping past and future fire regimes in the northwestern US and the implications for ecosystem management. For. Ecol. Manag. 2003, 178, 5-21. [CrossRef]

15. Falk, D.A.; Miller, C.; McKenzie, D.; Black, A.E. Cross-scale analysis of fire regimes. Ecosystems 2007, 10, 809-823. [CrossRef]

16. Reynolds, R.T.; Meador, A.J.S.; Youtz, J.A.; Nicolet, T.; Matonis, M.S.; Jackson, P.L.; DeLorenzo, D.G.; Graves, A.D. Restoring Composition and Structure in Southwestern Frequent-Fire Forests; General Technical Report RMRS-GTR-310; USDA Forest Service, Rocky Mountain Research Station: Fort Collins, CO, USA, 2013.

17. Allen, C.D.; Savage, M.; Falk, D.A.; Suckling, K.F.; Swetnam, T.W.; Schulke, T.; Stacey, P.B.; Morgan, P.; Hoffman, M.; Klingel, J.T. Ecological restoration of southwestern ponderosa pine ecosystems: A broad perspective. Ecol. Appl. 2002, 12, 1418-1433. [CrossRef]

18. Covington, W.W.; Fule, P.Z.; Moore, M.M.; Hart, S.C.; Kolb, T.E.; Mast, J.N.; Sackett, S.S.; Wagner, M.R. Restoring ecosystem health in ponderosa pine forests of the Southwest. J. For. 1997, 95, 23-29.

19. Covington, W.W.; Moore, M.M. Southwestern ponderosa forest structure: Changes since euro-american settlement. J. For. 1994, 92, 39-47.

20. Steele, R.; Arno, S.F.; Geier-Hayes, K. Wildfire patterns change in central Idaho's ponderosa pine-Douglas-fir forest. West. J. Appl. For. 1986, 1, 16-18.

21. Westerling, A.L.; Hidalgo, H.G.; Cayan, D.R.; Swetnam, T.W. Warming and earlier spring increase western U.S. Forest wildfire activity. Science 2006, 313, 940-943. [CrossRef]

22. Swetnam, T.W.; Farella, J.; Roos, C.I.; Liebmann, M.J.; Falk, D.A.; Allen, C.D. Multiscale perspectives of fire, climate and humans in western North America and the Jemez mountains, USA. Phil. Trans. R. Soc. B 2016, 371, 20150168. [CrossRef] [PubMed]

23. Savage, M.; Mast, J.N. How resilient are southwestern ponderosa pine forests after crown fires? Can. J. For. Res. 2005, 35, 967-977. [CrossRef]

24. Miller, C.; Abatzoglou, J.; Brown, T.; Syphard, A.D. Wilderness fire management in a changing environment. In The Landscape Ecology of Fire; McKenzie, D., Miller, C., Falk, D.A., Eds.; Springer: Berlin, Germany, 2011; pp. 269-294.

25. Littell, J.S.; Peterson, D.L.; Riley, K.L.; Liu, Y.; Luce, C.H. A review of the relationships between drought and forest fire in the United States. Glob. Chang. Biol. 2016, 22, 2353-2369. [CrossRef] [PubMed]

26. Westerling, A.L.; Swetnam, T.W. Interannual to decadal drought and wildfire in the western United States. EOS Trans. Am. Geophys. Union 2003, 84, 545-555. [CrossRef]

27. Flannigan, M.D.; Amiro, B.D.; Logan, K.A.; Stocks, B.J.; Wotton, B.M. Forest fires and climate change in the 21st century. Mitig. Adapt. Strateg. Glob. Chang. 2006, 11, 847-859. [CrossRef]

28. Abatzoglou, J.T.; Williams, A.P. Impact of anthropogenic climate change on wildfire across western US forests. Proc. Natl. Acad. Sci. USA 2016, 113, 11770-11775. [CrossRef]

29. Drever, C.R.; Peterson, G.; Messier, C.; Bergeron, Y.; Flannigan, M. Can forest management based on natural disturbances maintain ecological resilience? Can. J. For. Res. 2006, 36, 2285-2299. [CrossRef]

30. Turner, M.G. Disturbance and landscape dynamics in a changing world 1. Ecology 2010, 91, $2833-2849$. [CrossRef] [PubMed]

31. Falk, D.A. The resilience dilemma: Incorporating global change into ecosystem policy and management. Ariz. State Law J. 2016, 48, 145-156.

32. Littell, J.S.; McKenzie, D.; Peterson, D.L.; Westerling, A.L. Climate and wildfire area burned in western US ecoprovinces, 1916-2003. Ecol. Appl. 2009, 19, 1003-1021. [CrossRef] [PubMed]

33. Schoennagel, T.; Balch, J.K.; Brenkert-Smith, H.; Dennison, P.E.; Harvey, B.J.; Krawchuk, M.A.; Mietkiewicz, N.; Morgan, P.; Moritz, M.A.; Rasker, R. Adapt to more wildfire in western North American forests as climate changes. Proc. Natl. Acad. Sci. USA 2017, 114, 4582-4590. [CrossRef] [PubMed]

34. Stephens, S.L.; McIver, J.D.; Boerner, R.E.J.; Fettig, C.J.; Fontaine, J.B.; Hartsough, B.R.; Kennedy, P.L.; Schwilk, D.W. The effects of forest fuel-reduction treatments in the United States. BioScience 2012, 62, 549-560. [CrossRef] 
35. Svenning, J.-C.; Sandel, B. Disequilibrium vegetation dynamics under future climate change. Am. J. Bot. 2013, 100, 1266-1286. [CrossRef] [PubMed]

36. Stephens, S.L.; Agee, J.K.; Fulé, P.; North, M.; Romme, W.; Swetnam, T.; Turner, M.G. Managing forests and fire in changing climates. Science 2013, 342, 41-42. [CrossRef] [PubMed]

37. Folke, C.; Carpenter, S.; Walker, B.; Scheffer, M.; Elmqvist, T.; Gunderson, L.; Holling, C.S. Regime shifts, resilience, and biodiversity in ecosystem management. Annu. Rev. Ecol. Evol. Syst. 2004, 35, 557-581. [CrossRef]

38. Millar, C.I.; Stephenson, N.L.; Stephens, S.L. Climate change and forests of the future: Managing in the face of uncertainty. Ecol. Appl. 2007, 17, 2145-2151. [CrossRef] [PubMed]

39. Rollins, M.G. Landfire: A nationally consistent vegetation, wildland fire, and fuel assessment. Int. J. Wildl. Fire 2009, 18, 235-249. [CrossRef]

40. Anderson, R.S.; Jass, R.B.; Toney, J.L.; Allen, C.D.; Cisneros-Dozal, L.M.; Hess, M.; Heikoop, J.; Fessenden, J. Development of the mixed conifer forest in northern New Mexico and its relationship to holocene environmental change. Quat. Res. 2008, 69, 263-275. [CrossRef]

41. Touchan, R.; Allen, C.D.; Swetnam, T.W. Fire History and Climatic Patterns in Ponderosa Pine and Mixed-Conifer Forests of the Jemez Mountains, Northern New Mexico; U.S. Department of Agriculture, Forest Service, Rocky Mountain Research Station: Fort Collins, CO, USA, 1996; pp. 33-46.

42. Muldavin, E.; Kennedy, A.; Jackson, C.; Neville, P.; Neville, T.; Schultz, K.; Reid, M. Vegetation Classification and Map: Bandelier National Monument; Natural Resource Technical Report NPS/SCPN/NRTR—2011/438; National Park Service: Fort Collins, CO, USA, 2011; p. 468.

43. Margolis, E.Q.; Malevich, S.B. Historical dominance of low-severity fire in dry and wet mixed-conifer forest habitats of the endangered terrestrial Jemez mountains salamander (Plethodon neomexicanus). For. Ecol. Manag. 2016, 375, 12-26. [CrossRef]

44. Swetnam, T.W.; Baisan, C.H. Historical fire regime patterns in the southwestern United States since ad 1700. In Fire Effects in Southwestern Forests: Proceedings of the 2nd La Mesa Fire Symposium; General Technical Report RM-GTR-286; Allen, C., Ed.; U.S. Department of Agriculture, Forest Service, Rocky Mountain Research Station: Fort Collins, CO, USA, 1996; pp. 11-32.

45. Swetnam, T.W.; Baisan, C.H. Tree-ring reconstructions of fire and climate history in the Sierra Nevada and southwestern United States. In Fire and Climatic Change in Temperate Ecosystems of the Western Americas; Veblen, T.T., Baker, W.L., Montenegro, G., Swetnam, T.W., Eds.; Springer: New York, NY, USA, 2003; Volume 160, pp. 158-195.

46. Allen, C.D. Interactions across spatial scales among forest dieback, fire, and erosion in northern New Mexico landscapes. Ecosystems 2007, 10, 797-808. [CrossRef]

47. Coop, J.D.; Parks, S.A.; McClernan, S.R.; Holsinger, L.M. Influences of prior wildfires on vegetation response to subsequent fire in a reburned southwestern landscape. Ecol. Appl. 2016, 26, 346-354. [CrossRef] [PubMed]

48. Vankat, J.L. Post-1935 changes in forest vegetation of Grand Canyon National Park, Arizona, USA: Part 1-ponderosa pine forest. For. Ecol. Manag. 2011, 261, 309-325. [CrossRef]

49. Vankat, J.L. Post-1935 changes in forest vegetation of Grand Canyon National Park, Arizona, USA: Part 2-mixed conifer, spruce-fir, and quaking aspen forests. For. Ecol. Manag. 2011, 261, 326-341. [CrossRef]

50. Bradshaw, L.; McCormick, E. FireFamily Plus User's Guide, Version 2.0; Gen. Tech. Rep. RMRS-GTR-67WWW; U.S. Department of Agriculture, Forest Service, Rocky Mountain Research Station: Ogden, UT, USA, 2000.

51. NCEI, N. 1981-2010 U.S. Climate Normals; National Oceanic and Atmospheric Administration, National Centers for Environmental Information: Asheville, NC, USA, 2011.

52. Fulé, P.Z.; Crouse, J.E.; Heinlein, T.A.; Moore, M.M.; Covington, W.W.; Verkamp, G. Mixed-severity fire regime in a high-elevation forest of Grand Canyon, Arizona, USA. Landsc. Ecol. 2003, 18, 465-486. [CrossRef]

53. Fulé, P.Z.; Heinlein, T.A.; Covington, W.W.; Moore, M.M. Assessing fire regimes on Grand Canyon landscapes with fire-scar and fire-record data. Int. J. Wildl. Fire 2003, 12, 129-145. [CrossRef]

54. White, M.A.; Vankat, J.L. Middle and high elevation coniferous forest communities of the north rim region of Grand Canyon National Park, Arizona, USA. Vegetatio 1993, 109, 161-174. [CrossRef]

55. Yocom-Kent, L.L.; Fulé, P.Z.; Bunn, W.A.; Gdula, E.G. Historical high-severity fire patches in mixed-conifer forests. Can. J. For. Res. 2015, 45, 1587-1596. [CrossRef]

56. U.S. Forest Service. Warm Fire Assessment: Post-Fire Conditions and Management Considerations; U.S. Forest Service, North Kaibab Ranger District, Kaibab National Forest: Coconino County, AZ, USA, 2007. 
57. Clark, J.A.; Loehman, R.A.; Keane, R.E. Climate changes and wildfire alter vegetation of Yellowstone National Park, but forest cover persists. Ecosphere 2017, 8. [CrossRef]

58. Holsinger, L.; Keane, R.E.; Isaak, D.J.; Eby, L.; Young, M.K. Relative effects of climate change and wildfires on stream temperatures: A simulation modeling approach in a Rocky Mountain watershed. Clim. Chang. 2014, 124, 191-206. [CrossRef]

59. Loehman, R.A.; Clark, J.A.; Keane, R.E. Modeling effects of climate change and fire management on western white pine (Pinus monticola) in the northern Rocky Mountains, USA. Forests 2011, 2, 832-860. [CrossRef]

60. Loehman, R.A.; Keane, R.E.; Holsinger, L.M.; Wu, Z. Interactions of landscape disturbances and climate change dictate ecological pattern and process: Spatial modeling of wildfire, insect, and disease dynamics under future climates. Landsc. Ecol. 2017, 32, 1447-1459. [CrossRef]

61. Keane, R.E.; Loehman, R.A.; Holsinger, L.M. The FireBGCv2 Landscape Fire and Succession Model: A Research Simulation Platform for Exploring Fire and Vegetation Dynamics; Gen. Tech. Rep. RMRS-GTR-255; U.S. Department of Agriculture, Forest Service, Rocky Mountain Research Station: Fort Collins, CO, USA, 2011; p. 137.

62. Thornton, P.E.; Running, S.W. An improved algorithm for estimating incident daily solar radiation from measurements of temperature, humidity, and precipitation. Agric. For. Meteorol. 1999, 93, 211-228. [CrossRef]

63. Hungerford, R.D.; Nemani, R.R.; Running, S.W.; Coughlan, J.C. Mtclim: A Mountain Microclimate Simulation Model. Gen. Tech. Rep. Int-414; U.S. Department of Agriculture, Forest Service, Intermountain Research Station: Ogden, UT, USA, 1989; p. 52.

64. Schussman, H.; Enquist, C.; List, M. Historic Fire Return Intervals for Arizona and New Mexico: A Regional Perspective for Southwestern Land Managers; The Nature Conservancy: Phoenix, AZ, USA, 2006.

65. Paysen, T.E.; Ansley, R.J.; Brown, J.K.; Gottfried, G.J.; Haase, S.M.; Harrington, M.G.; Narog, M.G.; Sackett, S.S.; Wilson, R.C. Fire in western shrubland, woodland, and grassland ecosystems. In Wildland Fire in Ecosystems: Effects of Fire on Flora. Gen. Tech. Rep. RMRS-GTR-42-Vol 2; U.S. Department of Agriculture, Forest Service: Ogden, UT, USA, 2000; Volume 2, pp. 121-159.

66. O'Connor, C.D.; Lynch, A.M.; Falk, D.A.; Swetnam, T.W. Post-fire forest dynamics and climate variability affect spatial and temporal properties of spruce beetle outbreaks on a sky island mountain range. For. Ecol. Manag. 2015, 336, 148-162. [CrossRef]

67. Margolis, E.Q. Fire regime shift linked to increased forest density in a piñon-juniper savanna landscape. Int. J. Wildl. Fire 2014, 23, 234-245. [CrossRef]

68. Huffman, D.W.; Fule, P.Z.; Pearson, K.M.; Crouse, J.E. Fire history of pinyon-juniper woodlands at upper ecotones with ponderosa pine forests in Arizona and New Mexico. Can. J. For. Res. 2008, 38, 2097-2108. [CrossRef]

69. Gottfried, G.J.; Swetnam, T.W.; Allen, C.D.; Betancourt, J.L.; Chung-MacCoubrey, A.L. Pinyon-juniper woodlands. In Ecology, Diversity, and Sustainability of the Middle Rio Grande Basin; U.S. Forest Service Technical Report; Finch, D.M., Tainter, J.A., Eds.; USDA Forest Service: Fort Collins, CO, USA, 1995; Volume RM-GTR-268, pp. 95-132.

70. Brown, P.M.; Kaye, M.W.; Huckaby, L.S.; Baisan, C.H. Fire history along environmental gradients in the sacramento mountains, New Mexico: Influences of local patterns and regional processes. Ecoscience 2001, 8, 115-126. [CrossRef]

71. Baisan, C.H.; Swetnam, T.W. Fire history on a desert mountain range: Rincon mountain wilderness, Arizona, USA. Can. J. For. Res. 1990, 20, 1559-1569. [CrossRef]

72. Abella, S.R.; Fulé, P.Z. Fire Effects on Gambel Oak in Southwestern Ponderosa Pine-Oak Forests. USDA Forest Service Research Note RMRS-RN-34; USDA Forest Service: Fort Collins, CO, USA, 2008; p. 6.

73. Allen, C.D.; Touchan, R.; Swetnam, T.W. Overview of fire history in the Jemez mountains, New Mexico. In Proceedings of the New Mexico Geological Society Forty-seventh Annual Field Conference, Albuquerque, NM, USA, 25-28 September 1996; Goff, F., Kues, B.S., Rogers, M.A., McFadden, L.D., Gardner, J.N., Eds.; pp. 35-36.

74. Keane, R.E.; Ryan, K.C.; Running, S.W. Simulating effects of fire on northern Rocky Mountain landscapes with the ecological process model Fire-BGC. Tree Physiol. 1996, 16, 319-331. [CrossRef] [PubMed]

75. Gottfried, G.J. Pinyon-juniper woodlands in the southwestern United States. In Ecology and Management of Forests, Woodlands, and Shrublands in the Dryland Regions of the United States and Mexico: Perspectives for the 21st Century; University of Arizona: Tucson, AZ, USA, 1999; pp. 53-68. 
76. FEIS. Fire Effects Information System [online]; U.S. Department of Agriculture, Forest Service, Rocky Mountain Research Station, Fire Sciences Laboratory: Missoula, MT, USA, 2015.

77. Fulé, P.Z.; Covington, W.W.; Moore, M.M. Determining reference conditions for ecosystem management of southwestern ponderosa pine forests. Ecol. Appl. 1997, 7, 895-908. [CrossRef]

78. Chojnacky, D.C. Volume equations for New Mexico's pinyon-juniper dryland forests; Research Paper INT-471; Department of Agriculture, Forest Service, Intermountain Research Experiment Station: Ogden, UT, USA, 1994; 10p.

79. Scheller, R.M.; Domingo, J.B.; Sturtevant, B.R.; Williams, J.S.; Rudy, A.; Gustafson, E.J.; Mladenoff, D.J. Design, development, and application of LANDIS-II, a spatial landscape simulation model with flexible temporal and spatial resolution. Ecol. Model. 2007, 201, 409-419. [CrossRef]

80. Flatley, W.T.; Fulé, P.Z. Are historical fire regimes compatible with future climate? Implications for forest restoration. Ecosphere 2016, 7. [CrossRef]

81. Scheller, R.M.; Mladenoff, D.J. A forest growth and biomass module for a landscape simulation model, LANDIS: Design, validation, and application. Ecol. Model. 2004, 180, 211-229. [CrossRef]

82. Crookston, N.L.; Rehfeldt, G.E.; Dixon, G.E.; Weiskittel, A.R. Addressing climate 246 change in the forest vegetation simulator to assess impacts on landscape forest 247 dynamics. For. Ecol. Manag. 2010, 260, 1198-1211. [CrossRef]

83. Sturtevant, B.R.; Scheller, R.M.; Miranda, B.R.; Shinneman, D.; Syphard, A. Simulating dynamic and mixed-severity fire regimes: A process-based fire extension for LANDIS-ii. Ecol. Model. 2009, 220, 3380-3393. [CrossRef]

84. Gustafson, E.J.; Shifley, S.R.; Mladenoff, D.J.; Nimerfro, K.K.; He, H.S. Spatial simulation of forest succession and timber harvesting using LANDIS. Can. J. For. Res. 2000, 30, 32-43. [CrossRef]

85. Meehl, G.A.; Washington, W.M.; Arblaster, J.M.; Hu, A.; Teng, H.; Tebaldi, C.; Sanderson, B.N.; Lamarque, J.-F.; Conley, A.; Strand, W.G. Climate system response to external forcings and climate change projections in CCSM4. J. Clim. 2012, 25, 3661-3683. [CrossRef]

86. Van Vuuren, D.P.; Edmonds, J.; Kainuma, M.; Riahi, K.; Thomson, A.; Hibbard, K.; Hurtt, G.C.; Kram, T.; Krey, V.; Lamarque, J.-F. The representative concentration pathways: An overview. Clim. Chang. 2011, 109, 5. [CrossRef]

87. Collins, M.; Knutti, R.; Arblaster, J.; Dufresne, J.-L.; Fichefet, T.; Friedlingstein, P.; Gao, X.; Gutowski, W.; Johns, T.; Krinner, G. Long-term climate change: Projections, commitments and irreversibility. In Climate Change 2013: The Physical Science Basis. Contribution of Working Group i to the Fifth Assessment Report of the Intergovernmental Panel on Climate Change; Stocker, T.F., Qin, D., Plattner, G.-K., Tignor, M., Allen, S.K., Boschung, J., Nauels, A., Xia, Y., Bex, V., Midgley, P.M., Eds.; Cambridge University Press: Cambridge, UK; New York, NY, USA, 2013; pp. 1029-1136.

88. Jones, C.; Hughes, J.; Bellouin, N.; Hardiman, S.; Jones, G.; Knight, J.; Liddicoat, S.; O’Connor, F.; Andres, R.J.; Bell, C. The HadGEM2-ES implementation of CMIP5 centennial simulations. Geosci. Model Dev. 2011, 4, 543. [CrossRef]

89. Thrasher, B.; Xiong, J.; Wang, W.; Melton, F.; Michaelis, A.; Nemani, R. Downscaled climate projections suitable for resource management. EOS Trans. Am. Geophys. Union 2013, 94, 321-323. [CrossRef]

90. Ekström, M.; Grose, M.R.; Whetton, P.H. An appraisal of downscaling methods used in climate change research. Wiley Interdiscip. Rev. Clim. Chang. 2015, 6, 301-319. [CrossRef]

91. Snover, A.K.; Hamlet, A.F.; Lettenmaier, D.P. Climate-change scenarios for water planning studies: Pilot applications in the Pacific Northwest. Bull. Am. Meteorol. Soc. 2003, 84, 1513-1518.

92. U.S. Department of Agriculture, Forest Service (USFS). Final Environmental Impact Statement for the Southwest Jemez Mountains Landscape Restoration Project, Santa Fe National Forest, Sandoval County, New Mexico; U.S. Department of Agriculture, Forest Service: Washington, DC, USA, 2015.

93. Morgan, P.; Bunting, S.C.; Black, A.E.; Merrill, T.; Barrett, S. Fire regimes in the interior columbia river basin: Past and present. In USDA Forest Service, Rocky Mountain Research Station Final Report for RJVA-INT-94913; Fire Sciences Laboratory: Missoula, MT, USA, 1996.

94. Marlon, J.R.; Bartlein, P.J.; Gavin, D.G.; Long, C.J.; Anderson, R.S.; Briles, C.E.; Brown, K.J.; Colombaroli, D.; Hallett, D.J.; Power, M.J. Long-term perspective on wildfires in the western USA. Proc. Natl. Acad. Sci. USA 2012, 109, E535-E543. [CrossRef] [PubMed] 
95. Parks, S.A.; Miller, C.; Parisien, M.-A.; Holsinger, L.M.; Dobrowski, S.Z.; Abatzoglou, J. Wildland fire deficit and surplus in the western United States, 1984-2012. Ecosphere 2015, 6, 1-13. [CrossRef]

96. Wolf, J.J.; Mast, J.N. Fire history of mixed-conifer forests on the north rim, Grand Canyon National Park, Arizona. Phys. Geogr. 1998, 19, 1-14.

97. Running, S.W. Is global warming causing more, larger wildfires? Science 2006, 313, 927-928. [CrossRef] [PubMed]

98. Adams, M.A. Mega-fires, tipping points and ecosystem services: Managing forests and woodlands in an uncertain future. For. Ecol. Manag. 2013, 294, 250-261. [CrossRef]

99. Fulé, P.Z.; Swetnam, T.W.; Brown, P.M.; Falk, D.A.; Peterson, D.L.; Allen, C.D.; Aplet, G.H.; Battaglia, M.A.; Binkley, D.; Farris, C. Unsupported inferences of high-severity fire in historical dry forests of the western United States: Response to Williams and Baker. Glob. Ecol. Biogeogr. 2014, 23, 825-830. [CrossRef]

100. Savage, M.; Mast, J.N.; Feddema, J.J. Double whammy: High-severity fire and drought in ponderosa pine forests of the Southwest. Can. J. For. Res. 2013, 43, 570-583. [CrossRef]

101. Millar, C.I.; Stephenson, N.L. Temperate forest health in an era of emerging megadisturbance. Science 2015, 349, 823-826. [CrossRef] [PubMed]

102. Jones, J.; DeByle, N.; Winokur, R. Aspen: Ecology and management in the western United States. In USDA Forest Service, Rocky Mountain Forest and Range Experiment Station General Technical Report RM-119; USDA Forest Service, Rocky Mountain Forest and Range Experiment Station: Fort Collins, CO, USA, 1985.

103. Schoennagel, T.; Veblen, T.T.; Romme, W.H. The interaction of fire, fuels, and climate across Rocky Mountain forests. BioScience 2004, 54, 661-676. [CrossRef]

104. Margolis, E.Q.; Swetnam, T.W.; Allen, C.D. Historical stand-replacing fire in upper montane forests of the Madrean Sky Islands and Mogollon Plateau, southwestern USA. Fire Ecol. 2011, 7, 88-107. [CrossRef]

105. Romme, W.H.; Allen, C.D.; Bailey, J.D.; Baker, W.L.; Bestelmeyer, B.T.; Brown, P.M.; Eisenhart, K.S.; Floyd, M.L.; Huffman, D.W.; Jacobs, B.F. Historical and modern disturbance regimes, stand structures, and landscape dynamics in pinon-juniper vegetation of the western United States. Rangel. Ecol. Manag. 2009, 62, 203-222. [CrossRef]

106. Ganey, J.L.; Vojta, S.C. Tree mortality in drought-stressed mixed-conifer and ponderosa pine forests, Arizona, USA. For. Ecol. Manag. 2011, 261, 162-168. [CrossRef]

107. Allen, C.D.; Macalady, A.K.; Chenchouni, H.; Bachelet, D.; McDowell, N.; Vennetier, M.; Kitzberger, T.; Rigling, A.; Breshears, D.D.; Hogg, E.T. A global overview of drought and heat-induced tree mortality reveals emerging climate change risks for forests. For. Ecol. Manag. 2010, 259, 660-684. [CrossRef]

108. Van Mantgem, P.J.; Stephenson, N.L.; Byrne, J.C.; Daniels, L.D.; Franklin, J.F.; Fule, P.Z.; Harmon, M.E.; Larson, A.J.; Smith, J.M.; Taylor, A.H.; et al. Widespread increase of tree mortality rates in the western United States. Science 2009, 323, 521-524. [CrossRef] [PubMed]

109. Williams, A.P.; Allen, C.D.; Macalady, A.K.; Griffin, D.; Woodhouse, C.A.; Meko, D.M.; Swetnam, T.W.; Rauscher, S.A.; Seager, R.; Grissino-Mayer, H.D. Temperature as a potent driver of regional forest drought stress and tree mortality. Nat. Clim. Chang. 2013, 3, 292-297. [CrossRef]

110. Williams, A.P.; Allen, C.D.; Millar, C.I.; Swetnam, T.W.; Michaelsen, J.; Still, C.J.; Leavitt, S.W. Forest responses to increasing aridity and warmth in the southwestern United States. Proc. Natl. Acad. Sci. USA 2010, 107, 21289-21294. [CrossRef] [PubMed]

111. Jones, J.R.; DeByle, N.V.; Winokur, R.P. Climates. General Technical Report RM-119. In Aspen: Ecology and Management in the Western United States; DeByle, N.V., Winokur, R.P., Eds.; USDA Forest Service Rocky Mountain Forest and Range Experiment Station: Fort Collins, CO, USA, 1985; pp. 57-64.

112. Fulé, P.Z.; Covington, W.W.; Moore, M.M.; Heinlein, T.A.; Waltz, A.E.M. Natural variability in forests of the Grand Canyon, USA. J. Biogeogr. 2002, 29, 31-47. [CrossRef]

113. Diggins, C.; Fulé, P.Z.; Kaye, J.P.; Covington, W.W. Future climate affects management strategies for maintaining forest restoration treatments. Int. J. Wildl. Fire 2010, 19, 903. [CrossRef]

114. Brook, B.W.; Ellis, E.C.; Perring, M.P.; Mackay, A.W.; Blomqvist, L. Does the terrestrial biosphere have planetary tipping points? Trends Ecol. Evol. 2013, 28, 396-401. [CrossRef]

115. Reyer, C.P.; Brouwers, N.; Rammig, A.; Brook, B.W.; Epila, J.; Grant, R.F.; Holmgren, M.; Langerwisch, F.; Leuzinger, S.; Lucht, W. Forest resilience and tipping points at different spatio-temporal scales: Approaches and challenges. J. Ecol. 2015, 103, 5-15. [CrossRef] 
116. Scheller, R.M.; Kretchun, A.M.; Loudermilk, E.L.; Hurteau, M.D.; Weisberg, P.J.; Skinner, C. Interactions among fuel management, species composition, bark beetles, and climate change and the potential effects on forests of the lake tahoe basin. Ecosystems 2017. [CrossRef]

117. Falk, D.A. Are Madrean ecosystems approaching tipping points? Anticipating interactions of landscape disturbance and climate change. In Merging Science and Management in a Rapidly Changing World: Biodiversity and Management of the Madrean Archipelago; Proceedings RMRS-P-67; Ffolliott, P.F., Gottfried, G., Gebow, B., Eds.; U.S. Department of Agriculture, Forest Service, Rocky Mountain Research Station: Fort Collins, CO, USA, 2013; pp. 40-47.

118. Guiterman, C.H.; Margolis, E.Q.; Allen, C.D.; Falk, D.A.; Swetnam, T.W. Long-term persistence and fire resilience of oak shrubfields in dry conifer forests of northern New Mexico. Ecosystems 2017, 1-17. [CrossRef]

119. Allen, C.D.; Breshears, D.D. Drought-induced shift of a forest-woodland ecotone: Rapid landscape response to climate variation. Proc. Natl. Acad. Sci. USA 1998, 95, 14839-14842. [CrossRef]

120. Sanderson, C. Ecotone Conditions Along Piñon-Juniper and Ponderosa Pine Elevational Ranges, Jemez Mountains, NM. Master's Thesis, University of New Mexico, Albuquerque, NM, USA, 2015.

121. Hooper, D.U.; Chapin, F.S.; Ewel, J.J.; Hector, A.; Inchausti, P.; Lavorel, S.; Lawton, J.H.; Lodge, D.M.; Loreau, M.; Naeem, S.; et al. Effects of biodiversity on ecosystem functioning: A consensus of current knowledge. Ecol. Monogr. 2005, 75, 3-35. [CrossRef]

122. Diaz, S.; Cabido, M. Vive la difference: Plant functional diversity matters to ecosystem processes. Trends Ecol. Evol. 2001, 16, 646-655. [CrossRef]

123. McGlone, C.M.; Sieg, C.H.; Kolb, T.E. Invasion resistance and persistence: Established plants win, even with disturbance and high propagule pressure. Biol. Invasions 2011, 13, 291-304. [CrossRef]

124. Breshears, D.D.; Cobb, N.S.; Rich, P.M.; Price, K.P.; Allen, C.D.; Balice, R.G.; Romme, W.H.; Kastens, J.H.; Floyd, M.L.; Belnap, J.; et al. Regional vegetation die-off in response to global-change-type drought. Proc. Natl. Acad. Sci. USA 2005, 102, 15144-15148. [CrossRef]

125. Floyd, M.L.; Clifford, M.; Cobb, N.S.; Hanna, D.; Delph, R.; Ford, P.; Turner, D. Relationship of stand characteristics to drought-induced mortality in three southwestern piñon-juniper woodlands. Ecol. Appl. 2009, 19, 1223-1230. [CrossRef] [PubMed]

126. Stephens, S.L.; Moghaddas, J.J.; Edminster, C.; Fiedler, C.E.; Haase, S.; Harrington, M.; Keeley, J.E.; Knapp, E.E.; McIver, J.D.; Metlen, K.; et al. Fire treatment effects on vegetation structure, fuels, and potential fire severity in western U.S. Forests. Ecol. Appl. 2009, 19, 305-320. [CrossRef] [PubMed]

127. Fulé, P.Z.; Crouse, J.E.; Roccaforte, J.P.; Kalies, E.L. Do thinning and/or burning treatments in western USA ponderosa or Jeffrey pine-dominated forests help restore natural fire behavior? For. Ecol. Manag. 2012, 269, 68-81. [CrossRef]

128. Duveneck, M.J.; Scheller, R.M. Climate suitable planting as a strategy for maintaining forest productivity and functional diversity. Ecol. Appl. 2015, 25, 1653-1668. [CrossRef]

129. Williams, M.I.; Dumroese, R.K. Preparing for climate change: Forestry and assisted migration. J. For. 2013, 111, 287-297. [CrossRef]

130. Keane, R.E.; Cary, G.J.; Davies, I.D.; Flannigan, M.D.; Gardner, R.H.; Lavorel, S.; Lenihan, J.M.; Li, C.; Rupp, T.S. A classification of landscape fire succession models: Spatial simulations of fire and vegetation dynamics. Ecol. Modell. 2004, 179, 3-27. [CrossRef]

131. Ager, A.; Barros, A.; Preisler, H.; Day, M.; Spies, T.; Bailey, J.; Bolte, J. Effects of accelerated wildfire on future fire regimes and implications for the United States federal fire policy. Ecol. Soc. 2017, 22. [CrossRef]

132. McKenzie, D.; Gedalof, Z.E.; Peterson, D.L.; Mote, P. Climatic change, wildfire, and conservation. Conserv. Biol. 2004, 18, 890-902. [CrossRef]

133. Dominguez, F.; Cañon, J.; Valdes, J. Ipcc-ar4 climate simulations for the southwestern us: The importance of future enso projections. Clim. Chang. 2010, 99, 499-514. [CrossRef]

134. Geil, K.L.; Serra, Y.L.; Zeng, X. Assessment of CMIP5 model simulations of the North American monsoon system. J. Clim. 2013, 26, 8787-8801. [CrossRef]

135. Jardine, A.; Garfin, G.; Merideth, R.; Black, M.; LeRoy, S. Assessment of climate change in the southwest united states: A report prepared for the national climate assessment; Island Press: Washington DC, USA, 2013.

136. Bentz, B.J.; Régnière, J.; Fettig, C.J.; Hansen, E.M.; Hayes, J.L.; Hicke, J.A.; Kelsey, R.G.; Negrón, J.F.; Seybold, S.J. Climate change and bark beetles of the western United States and Canada: Direct and indirect effects. BioScience 2010, 60, 602-613. [CrossRef] 
137. Creeden, E.P.; Hicke, J.A.; Buotte, P.C. Climate, weather, and recent mountain pine beetle outbreaks in the western United States. For. Ecol. Manag. 2014, 312, 239-251. [CrossRef]

138. Stephenson, N.L. Making the transition to the third era of natural resources management. GWS J. Parks Prot. Areas Cult. Sites 2014, 31, 227-235.

139. Seastedt, T.R.; Hobbs, R.J.; Suding, K.N. Management of novel ecosystems: Are novel approaches required? Front. Ecol. Environ. 2008, 6, 547-553. [CrossRef]

(C) 2018 by the authors. Licensee MDPI, Basel, Switzerland. This article is an open access article distributed under the terms and conditions of the Creative Commons Attribution (CC BY) license (http://creativecommons.org/licenses/by/4.0/). 